OPEN ACCESS

Edited by:

Adele Brunetti,

National Research Council (CNR), Italy

Reviewed by:

Carmela Conidi,

Italian National Research Council, Italy

Alberto Tiraferri,

Politecnico di Torino, Italy

${ }^{*}$ Correspondence:

Luca Fortunato

luca.fortunato@kaust.edu.sa

Specialty section:

This article was submitted to

Separation Processes,

a section of the journal

Frontiers in Chemical Engineering

Received: 29 March 2021

Accepted: 19 April 2021

Published: 31 May 2021

Citation:

Novoa AF, Vrouwenvelder JS and

Fortunato L (2021) Membrane Fouling in Algal Separation Processes: A Review of Influencing Factors and

Mechanisms.

Front. Chem. Eng. 3:687422.

doi: 10.3389/fceng.2021.687422

\section{Membrane Fouling in Algal Separation Processes: A Review of Influencing Factors and Mechanisms}

\author{
Andres Felipe Novoa, Johannes S. Vrouwenvelder and Luca Fortunato* \\ Division of Biological and Environmental Science and Engineering (BESE), Water Desalination and Reuse Center (WDRC), \\ King Abdullah University of Science and Technology (KAUST), Thuwal, Saudi Arabia
}

The use of algal biotechnologies in the production of biofuels, food, and valuable products has gained momentum in recent years, owing to its distinctive rapid growth and compatibility to be coupled to wastewater treatment in membrane photobioreactors. However, membrane fouling is considered a main drawback that offsets the benefits of algal applications by heavily impacting the operation cost. Several fouling control strategies have been proposed, addressing aspects related to characteristics in the feed water and membranes, operational conditions, and biomass properties. However, the lack of understanding of the mechanisms behind algal biofouling and control challenges the development of cost-effective strategies needed for the long-term operation of membrane photobioreactors. This paper reviews the progress on algal membrane fouling and control strategies. Herein, we summarize information in the composition and characteristics of algal foulants, namely algal organic matter, cells, and transparent exopolymer particles; and review their dynamic responses to modifications in the feedwater, membrane surface, hydrodynamics, and cleaning methods. This review comparatively analyzes (i) efficiency in fouling control or mitigation, (ii) advantages and drawbacks, (iii) technological performance, and (iv) challenges and knowledge gaps. Ultimately, the article provides a primary reference of algal biofouling in membranebased applications.

Keywords: fouling, transparent exopolymer particles, algal organic matter, wastewater treatment, fouling control, cake layer, algae membrane photobioreactor

\section{INTRODUCTION}

Microalgae comprise a diverse group of prokaryotic and eukaryotic organisms capable of using $\mathrm{CO}_{2}$ and nutrients, such as nitrogen $(\mathrm{N})$ and phosphorous $(\mathrm{P})$, to produce organic matter and oxygen via photosynthesis (Roostaei and Zhang, 2017). Owing to its distinctive rapid growth and the versatility to be cultivated in a wide range of environments, the large-scale production of microalgae as a source of biofuels, food, and valuable products has gained momentum in recent years (Roostaei and Zhang, 2017; Tua et al., 2021). More recently, algal growth has been coupled to water treatment, employing wastewater as a feed containing nutrients necessary, such as carbon, nitrogen, and phosphorous (Kanchanatip et al., 2016; Luo et al., 2017; Sun et al., 2021). In addition to this, microalgae can be cultivated, utilizing $\mathrm{CO}_{2}$ from unconventional sources, such as power plants and cement manufacturing facilities, thus reducing carbon dioxide emissions (Senatore et al., 2021). Thereby, combining water treatment and algal production offsets the costs of both processes 


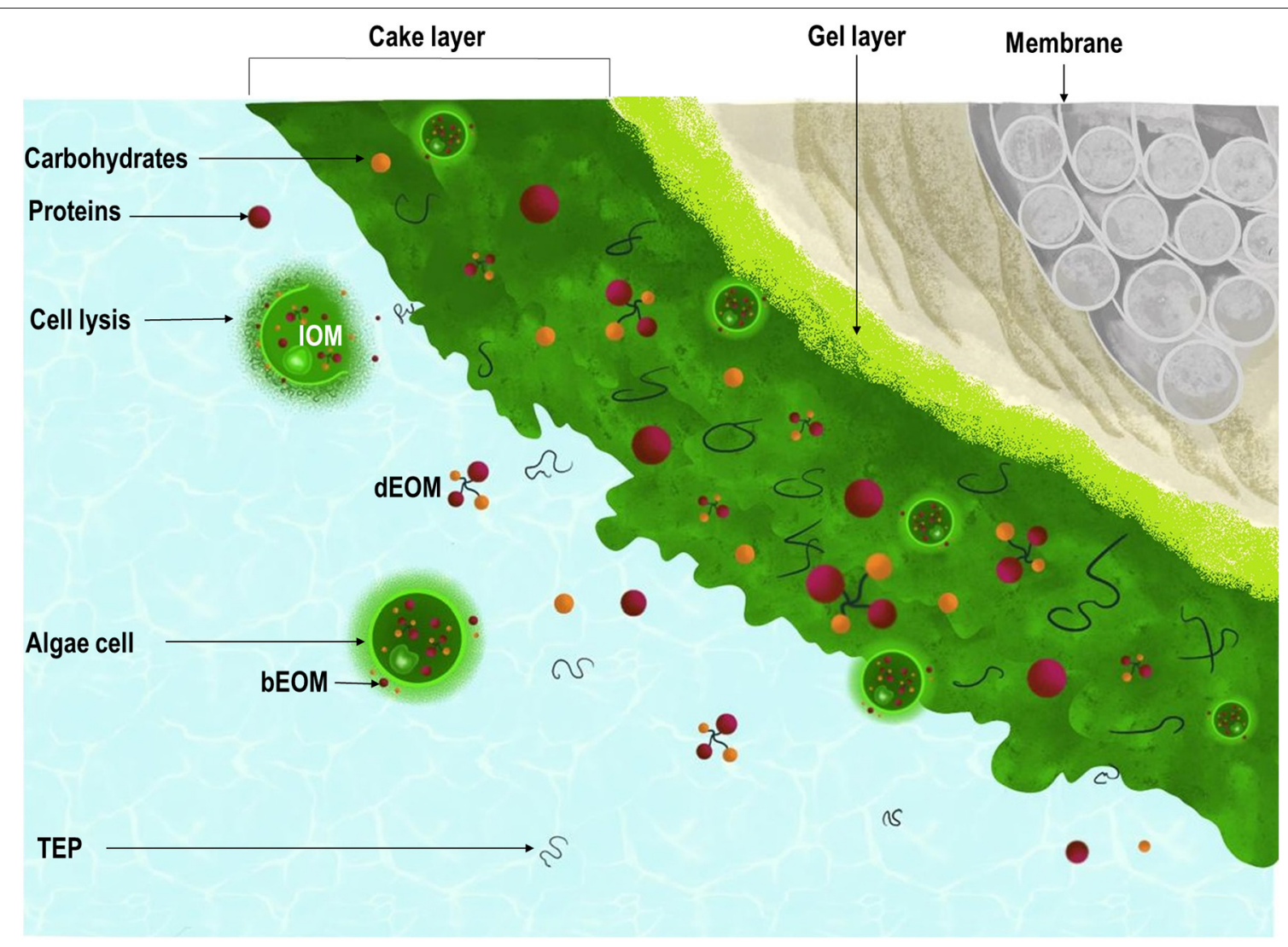

GRAPHICAL ABSTRACT | Schematic illustration of the interactions among algal cells, algal organic matter (AOM), and transparent exopolymer particles (TEP) in algal membrane fouling in separation processes. The external organic matter (EOM) is the AOM that results from the algal metabolic activity, while the internal organic matter (IOM) refers to the AOM released due to cell rupture. dEOM and bEOM refer, respectively, to the dissolved and bound fractions.

by optimizing the use of energy, water, and resources (Xu et al., 2015; Liao et al., 2018; Luo et al., 2019; Sun et al., 2021).

The potential benefits of algal biotechnologies are affected by their high production cost (Tua et al., 2021). Using wastewater might be a competitive source to replace energy-intensive commercial fertilizers, yet algal harvesting and dewatering remain as major challenges (Roostaei and Zhang, 2017; Alshahri et al., 2021a). In fact, it is estimated that $90 \%$ of the total cost of algal biomass production may come from harvesting and dewatering (Zhang et al., 2014), whereas the latter contributes up to $60-70 \%$ of the cost (Chen et al., 2012; Liao et al., 2018; Zhang and Fu, 2018; Zhang Y. et al., 2019). The traditional solid-liquid separation technologies for microalgae, such as coagulation/flocculation, centrifugation, gravity sedimentation, and dissolved air flotation, impact the capital expenses of algal production as they demand large amounts of energy, chemicals, or footprint (Bilad et al., 2014; Zhang and Fu, 2018). Compared with conventional microalgal separation processes, membrane technologies proved to be a cost and energy-efficient alternative for removing a wide range of particles and organisms, lowering the solid-liquid separation costs and reducing the chemicals consumption ( $\mathrm{Mu}$ et al., 2014; Xu et al., 2015; Gonçalves et al., 2017; Luo et al., 2017; Bamba et al., 2021; Senatore et al., 2021; Zhao et al., 2021a; Zheng et al., 2021). However, membrane fouling and the consequent decline in the permeate flux remain a major challenge to membrane applications on the cultivation, harvesting, and dewatering of algal biomass, as well as to downstream separation processes for recovery of value-added products (Adhikari and Pellegrino, 2015; Shi et al., 2019; Sun et al., 2021; Zhao et al., 2021a). Therefore, an increasing number of publications addressing algal fouling and membrane algal fouling have been published in recent years (Figure 1).

A broad number of studies have highlighted the influence of several factors affecting algal biofouling and separation performance (Le-Clech et al., 2005; Fletcher et al., 2011b; Krzeminski et al., 2017; Luo et al., 2017; Bagheri and Mirbagheri, 2018; Fortunato et al., 2020; Jiang et al., 2020; Zhou et al., 2020; Sun et al., 2021). These aspects include membrane characteristics, such as pore size and membrane materials; characteristics, such as algal species and cell size (Kanchanatip et al., 2016; Elcik and Cakmakci, 2017; Keyvan Hosseini et al., 2020); metabolic products, including fractions of proteins and carbohydrates (Kanchanatip et al., 2016; Shekhar et al., 2017; Wu et al., 2018; Luo et al., 2019; Zhang Z. et al., 2020; Zhou et al., 2020); and operating conditions, such as the hydraulic retention time (HRT) 


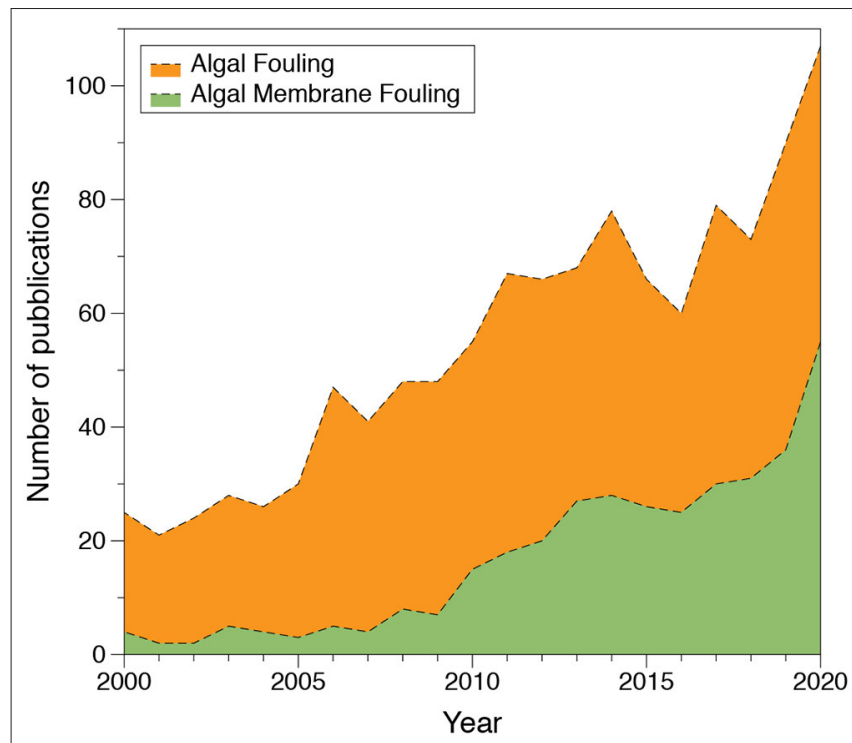

FIGURE 1 | Number of publications reported in the Scopus database on the topics of algal fouling.

and solids retention time (SRT) (Low et al., 2016; Novoa et al., 2020).

Considering the high fouling propensity in algal membrane separation processes, fouling control strategies are crucial to ensure their long-term operation (Eliseus et al., 2017; Zhang and Fu, 2018; Fortunato et al., 2020; Hua et al., 2020). Different strategies, including physical and chemical membrane cleaning, have been employed to increase the membrane life span and reduce the impact of fouling on the process (Zhao et al., 2021a). However, the increase in the consumption of energy and chemicals is a common drawback in fouling controls (Le-Clech et al., 2005; Fletcher et al., 2011b; Krzeminski et al., 2017; Luo et al., 2017; Bagheri and Mirbagheri, 2018). In this review, an updated summary of the contributing factors and the underlaying mechanisms to algal fouling is presented. It is found out that a comprehensive understanding of the dynamic interactions between foulants and the membrane during operation is critically important in the development and implementation of fouling control strategies.

\section{IMPACT OF ALGAL PRODUCTS ON FOULING MECHANISMS}

Membrane fouling is governed by the interactions between mixed liquor and the membrane, whereas the convective forces toward the membrane trigger the deposition of foulants on the surface. Over time, fouling results in a loss of water permeability through the membrane, thereby increasing transmembrane pressure (TMP) required to drive the process (Fletcher et al., 2011b; Bilad et al., 2014; Krzeminski et al., 2017). Fouling is commonly classified into different categories based on the foulants characteristics (i), permeability recovery (ii), or fouling mechanism (iii).

According to the origin of foulants, the fouling can be classified as organic, inorganic, or biofouling. Inorganic fouling, or scaling, results from the chemical precipitation of inorganic particles onto the membrane surface or into the membrane pores. Organic fouling includes extracellular polymeric substances (EPS), proteins, carbohydrates, and humic substances present in the algal organic matter (AOM). In algal membrane photobioreactors (MPBRs), the term biofouling mainly refers to the accumulation of algal cells, organic matter, and transparent exopolymer particles (TEP) (Fletcher et al., 2011b; Bilad et al., 2014; Wang et al., 2014; Liao et al., 2018; Zhang Z. et al., 2020). It is worth noting that, in algae processes, there is no clear distinction between organic fouling and biofouling, as, most of the time, they occur simultaneously.

Based on permeability recovery, fouling can be considered reversible, irreversible, or permanent. Reversible fouling usually refers to the fouling fraction that can be easily removed by physical cleaning such as backwash or relaxation. Irreversible fouling, on the other hand, is defined as the fraction that can be removed only by intensive chemical cleaning. Finally, permanent fouling is defined as the fraction that cannot be recovered by any cleansing agent (Fletcher et al., 2011b; Bilad et al., 2014; Wang et al., 2014) (Table 1).

A variety of membrane-foulant and foulant-foulant interactions result in different fouling mechanisms, namely, pore-blocking, pore-narrowing, and cake layer formation. The sorption of particles and colloidal substances with a size smaller than the membrane pores narrow the membrane channels, whereas the sorption of particles sized similar to the membrane pores causes pore-blocking (Fletcher et al., 2011b; Bilad et al., 2014; Wang et al., 2014; Marbelia et al., 2016; Elcik and Cakmakci, 2017; Krzeminski et al., 2017; Keyvan Hosseini et al., 2020; Novoa et al., 2020; Zhou et al., 2020). In contrast, particles and solutes with a size larger than that of the membrane pores, are rejected and accumulated on the membrane surface due to size exclusion, forming a cake layer. The cake layer is a complex matrix composed of foulants like cells, debris, inorganic colloidal particles, and AOM, which provides additional hydraulic resistance to the filtration and reduces the water permeability (Liao et al., 2018; Zhang and Fu, 2018; Zhang M. et al., 2019). The cake layer is often reversible, depending on its adhesive properties (Bin et al., 2017; Fortunato et al., 2020; Zhou et al., 2020). In fact, Bin et al. (2017) described higher reversible cake layer resistance when algal cells or debris is accumulated on the vicinity of the membrane surface, in divergence with cell debris and IOM that showed a greater tendency to irreversible fouling.

On the other side, it is worth mentioning the eventual positive impact of the cake layer: A compact and more resistant cake layer acts as a secondary filtration layer, protecting the membrane surface from small organics molecules responsible for irreversible fouling (Low et al., 2016; Fortunato et al., 2020; Novoa et al., 2020). Javadi et al. (2014) found out that an increase in the cake layer resistance, induced by a compact and nonporous structure, improved the permeate quality (Javadi et al., 
TABLE 1 | Definitions in fouling classification according to the permeability recovery, fouling mechanism, and cleaning efficiency.

\begin{tabular}{|c|c|c|c|}
\hline Permeability recovery & Fouling mechanism & Cleaning efficiency & References \\
\hline $\begin{array}{l}\text { Reversible: removed by } \\
\text { physical cleaning }\end{array}$ & $\begin{array}{l}\text { Cake layer: accumulation on } \\
\text { membrane surface }\end{array}$ & $\begin{array}{l}\text { High efficiency of physical, } \\
\text { chemical, and mechanical } \\
\text { cleaning }\end{array}$ & $\begin{array}{l}\text { Fletcher et al., 2011a; Wang et al., 2014; } \\
\text { Fortunato et al., 2017; Bagheri and } \\
\text { Mirbagheri, 2018; Mat Nawi et al., } 2020\end{array}$ \\
\hline $\begin{array}{l}\text { Irreversible: removed by } \\
\text { chemical cleaning }\end{array}$ & $\begin{array}{l}\text { Pore-narrowing and complete } \\
\text { pore blocking }\end{array}$ & $\begin{array}{l}\text { Partial efficiency of } \\
\text { mechanical and chemical } \\
\text { cleaning }\end{array}$ & $\begin{array}{l}\text { Bilad et al., 2014; Kanchanatip et al., } \\
\text { 2016; Bin et al., 2017; Liao et al., 2018; } \\
\text { Zhang and Fu, 2018; Keyvan Hosseini } \\
\text { et al., 2020; Novoa et al., 2020; Zhou } \\
\text { et al., } 2020\end{array}$ \\
\hline $\begin{array}{l}\text { Permanent: not removed by } \\
\text { any cleaning method }\end{array}$ & $\begin{array}{l}\text { Pore-narrowing and complete } \\
\text { pore blocking }\end{array}$ & $\begin{array}{l}\text { Low efficiency of mechanical } \\
\text { and chemical cleaning }\end{array}$ & \\
\hline
\end{tabular}

2014). This finding is in agreement with the reported positive effect of biofouling on MBR systems, whereby the accumulation of microbial EPS and SMP was found to further improve the rejection of organic micropollutants that would otherwise permeate UF/MF membrane pores (Deng et al., 2016; BouNehme Sawaya and Harb, 2021).

\section{STAGES OF ALGAL FOULING}

Algal biofouling results from the deposition and accumulation of AOM, algal cells, and TEP present in the mixed liquid solution (Fletcher et al., 2011b; Bilad et al., 2014; Wang et al., 2014; Liao et al., 2018; Zhou et al., 2020). The fouling in algal membrane processes is described as a three-stages process (Babel and Takizawa, 2010; Low et al., 2016). Biofouling is, hence, firstly built upon AOM coatings on the membrane surface during a stage named "conditioning fouling," characterized by strong membrane-foulant interactions that result in higher rates of pore-blocking and narrowing that depend on the interfacial electrochemistry and steric forces, and result in the formation of a gel layer and short TMP jumps. Thereupon, microfouling with colonies of unicellular algae is facilitated by the adsorbed and conditioned foulants; this second fouling stage, or slow fouling, results in a cake layer composed of multicellular algal complexes that lead to a linear TMP rise as the cake becomes thicker (Fletcher et al., 2011b; Bagheri and Mirbagheri, 2018; Liao et al., 2018). Finally, the third fouling stage is characterized by a sharp exponential rise in fouling rates, which is caused by the progressively heterogeneous distribution of foulants on the membrane surface and cake layer; the permeability in the fouled areas is hampered, and the flux is redirected toward less fouled areas wherein the critical flux is exceeded (Babel and Takizawa, 2010; Fletcher et al., 2011b; Bagheri and Mirbagheri, 2018; Novoa et al., 2020).

The first stage (conditioning fouling) is strongly influenced by the interactions between algal foulants and the membrane surface; these interactions are widely described by the extended Derjaguin-Landau-Verwey-Overbeek model (XDLVO) in terms of interfacial free energy variations $\left(\Delta G_{a d h}\right)$ before and after adhesion. The total free energy of adhesion is considered as the sum of acid-base (AB), van der Waals (LW), and electrostatic (EL) interactions (Blumreisinger et al., 1983; Ozkan and Berberoglu, 2013). LW originates from asymmetrical distributions of electrons, and it is usually attractive; on the other hand, EL interactions refer to the Coulombic interactions between foulants and a membrane; and, finally, the $\mathrm{AB}$ forces represent the attractive interactions between similarly hydrophobic species and the repulsive interactions between hydrophobic surfaces and hydrophilic species (Ozkan and Berberoglu, 2013). The magnitude of the total AB, LW, and EL interactions controls the reversibility of a foulant's adhesion (Blumreisinger et al., 1983).

As algal fouling develops, the membrane-cell interactions are weakened, and the fouling development is mostly influenced by the cell-cell and cell-AOM interactions in the cake layer (Fletcher et al., 2011b; Wu et al., 2013; Bilad et al., 2014; Kanchanatip et al., 2016; Marbelia et al., 2016; Elcik and Cakmakci, 2017; Ting et al., 2017; Liao et al., 2018; Zhang and Fu, 2018; Zhang M. et al., 2019). In fact, Zhou et al. (2020), Novoa et al. (2020), and Low et al. (2016) report that, in the continuous operation mode, upon the cake layer formation, the XDLVO forces are strongly weakened by convective and hydrodynamic forces. Similarly, Marbelia et al. found out that, in hydrophilic negatively charged membranes, the correlation between flux and XDLVO interactions decrease after $120 \mathrm{~min}$ of operation, as the deposition of foulants neutralizes the charge of the membrane surface, decreasing its ability to repel AOM and algal cells (Marbelia et al., 2016).

Despite the commonalities reported in the fouling development process of biological sludge and microalgae, the differences in foulants composition and their interactions with the membrane led to different fouling mechanisms (Fletcher et al., 2011b; Wu et al., 2013; Bilad et al., 2014; Kanchanatip et al., 2016; Marbelia et al., 2016; Elcik and Cakmakci, 2017; Ting et al., 2017; Liao et al., 2018; Zhang and Fu, 2018; Zhang M. et al., 2019). In algal processes, the cells present large sizes and are completely retained by UF and MF membranes, and, thus, the cake layer constitutes a significantly larger fraction of total fouling when compared with other processes, such as MBRs. Conversely, a gel layer and pore adsorption have been found to exert a larger contribution to membrane fouling in bacterial sludge processes (Deng et al., 2016). 


\section{ALGAL FOULANTS}

\section{Algal Cells}

The sizes, shapes, and surface properties strictly depend on the algae species (Liao et al., 2018; Zhang and Fu, 2018; Zhou et al., 2020). The algal sizes vary around 3-30 $\mu \mathrm{m}$, resulting bigger than the pore diameters of MF and UF membranes, and, thus, it becomes the primary constituent of the cake layer due to size exclusion (Zhang and Fu, 2018; Sun et al., 2021). A higher cake porosity is commonly observed in species with bigger cells (Bilad et al., 2013; Marbelia et al., 2016; Zhang and $\mathrm{Fu}, 2018$ ). Shekhar et al. (2017) investigated the relation between particle size and cake resistance in algal suspensions of Chlorella vulgaris and Chlamydomonas reinhardtii; the latter displayed a thicker cake layer and higher resistance to water permeation. Analogous results were reported by Marbelia et al. (2016), in studying the filterability of different algal species, using polyacrylonitrile (PAN) membranes; large particles, near to spherical shape and with a numeric narrow size distribution, led to a higher cake porosity and better filterability properties. Similarly, Bilad et al. found an enhancement in filterability when using cells with spherical shape and rigid cell walls, such as Chlorella vulgaris, in magnetically induced membrane vibrating (MMV) systems (Bilad et al., 2013); and Zhou et al. (2020) studied the size-dependent adhesive properties of Chlorella vulgaris and Scenedesmus obliquus that induced different filter abilities. To this extent, different results highlight that large, spherical, and rigid cells present the best filterability characteristics (Bilad et al., 2013; Marbelia et al., 2016; Liao et al., 2018; Zhang and Fu, 2018; Zhou et al., 2020).

Both cake layer compressibility and membrane performance are strongly affected by the cell walls rigidity (Zhang and Fu, 2018). Hereafter, algal species with rigid cell walls, as is the case of Chlorella and Phaeodactylum, lead to the formation of a rigid cake layer that exhibits low compressibility and, thereby, a constant porosity and better filterability over time (Baerdemaeker et al., 2013; Marbelia et al., 2016; Zhang and Fu, 2018; Zhang M. et al., 2019). In contrast, species with compressible cell walls, such as Nannochloropsis, are associated with sharper TMP increases and a significant reduction in permeability (Babel and Takizawa, 2010).

Another factor that contributes to membrane fouling is the biomass concentration, which increases the viscosity of the bulk medium and hinders the air scouring effect across the membrane surface (Fletcher et al., 2011b; Bagheri and Mirbagheri, 2018). Kanchanatip et al. reported a direct correlation between biomass concentration and flux decline; cell solids were found to contribute as primary foulants, leading to 63 and $86 \%$ water flux decrease when operating, respectively, at 10 and $40 \mathrm{~g} / \mathrm{L}$ (Kanchanatip et al., 2016). Similarly, Bamba et al. (2021) reported a permeate flux declined from 441 to $73 \mathrm{LMH}$ when the feed concentration of Chlorella vulgaris increased from 0.25 to $1 \mathrm{~g} / \mathrm{L}$.

It is worth noting that algal cell concentration cannot be considered a stand-alone parameter to describe the fouling propensity. Indeed, the cells are in suspension with large amounts of AOM (Javadi et al., 2014; Bamba et al., 2021). Thereby, indicators targeting the interactions between algal cells and AOM in solution, such as the shear rate efficiency and the particle size distribution (PSD), presented a better correlation with the fouling rates (Fletcher et al., 2011b; Javadi et al., 2014; Kanchanatip et al., 2016; Low et al., 2016).

The PSD elucidates the size properties of the particles that result from the dynamic equilibrium between formation, transformation, and breakage of algal aggregates (Barbusiński and Kościelniak, 1995). Smaller particles lead to a more compact and non-porous structure, exhibiting higher cake specific resistance when compared with larger particles (Marbelia et al., 2014; Bourcier et al., 2016). Bourcier et al. studied the impact of PSD in the specific cake resistance and compressibility; a broad and heterogeneous PSD was found to build a cake constituted by uneven layers with different particle sizes, where the smaller ones were prone to move between layers as the filtration pressure increased (Bourcier et al., 2016). In fact, the uneven deposition of particles with wide-size distribution at different locations in the cake layer negatively impacts the permeability, causing the flux to redistribute toward less-fouled areas and leading to a rapid rise in TMP (Fletcher et al., 2011b; Bourcier et al., 2016; Novoa et al., 2020).

\section{Algal Organic Matter (AOM)}

The soluble organic matter released by algae represents a main operational challenge in algal membrane processes since it strongly affects the membrane fouling potential (Luo et al., 2019). These compounds vary in chemical compositions and molecular weights, depending on several factors, including the algal characteristics, the nutrients availability, and the growth phase (Huang et al., 2012; Zhang et al., 2016; Zhuang et al., 2016). Common terms and classifications of AOM are presented in Figure 2.

Based on its molecular weight, the AOM can be classified into four categories: (1) high molecular weight (MW) biopolymers (>20,000 Da); (2) humic-like substances (500-20,000 Da); (3) medium molecular weight components, such as building blocks (350-500 Da); and (4) low-MW neutrals (<350 Da) (Zhang W. et al., 2013). High-MW biopolymers, due to size exclusion, tend to accumulate on the membrane surface, contributing to cake layer resistance (Zhang et al., 2016; Bin et al., 2017). Similarly, in a characterization of the organic compounds present in a MPBR, Luo et al. (2019) described the relation between rejection of organics and their molecular weight: Biopolymers were largely rejected ( $84 \%)$, followed by building blocks $(<42 \%)$ and low molecular weight compounds (42-63\%). Due to their size, low molecular weight compounds were reported to be more prone to penetrate into the membrane pores and cause poreblocking and irreversible fouling (Morineau-Thomas et al., 2002; Kanchanatip et al., 2016; Luo et al., 2019). Hence, the cake layer built upon high-MW biopolymers might result beneficial, as it acts as a secondary and reversible sieving layer that protects the membrane surface from irreversible low-MW foulants.

Proteins and carbohydrates present in the AOM exhibit hydrophilic and hydrophobic fractions that vary according to the algal species and growth phase (Zhang and $\mathrm{Fu}, 2018$ ). A larger hydrophilic fraction is reported in carbohydrates, characterized 


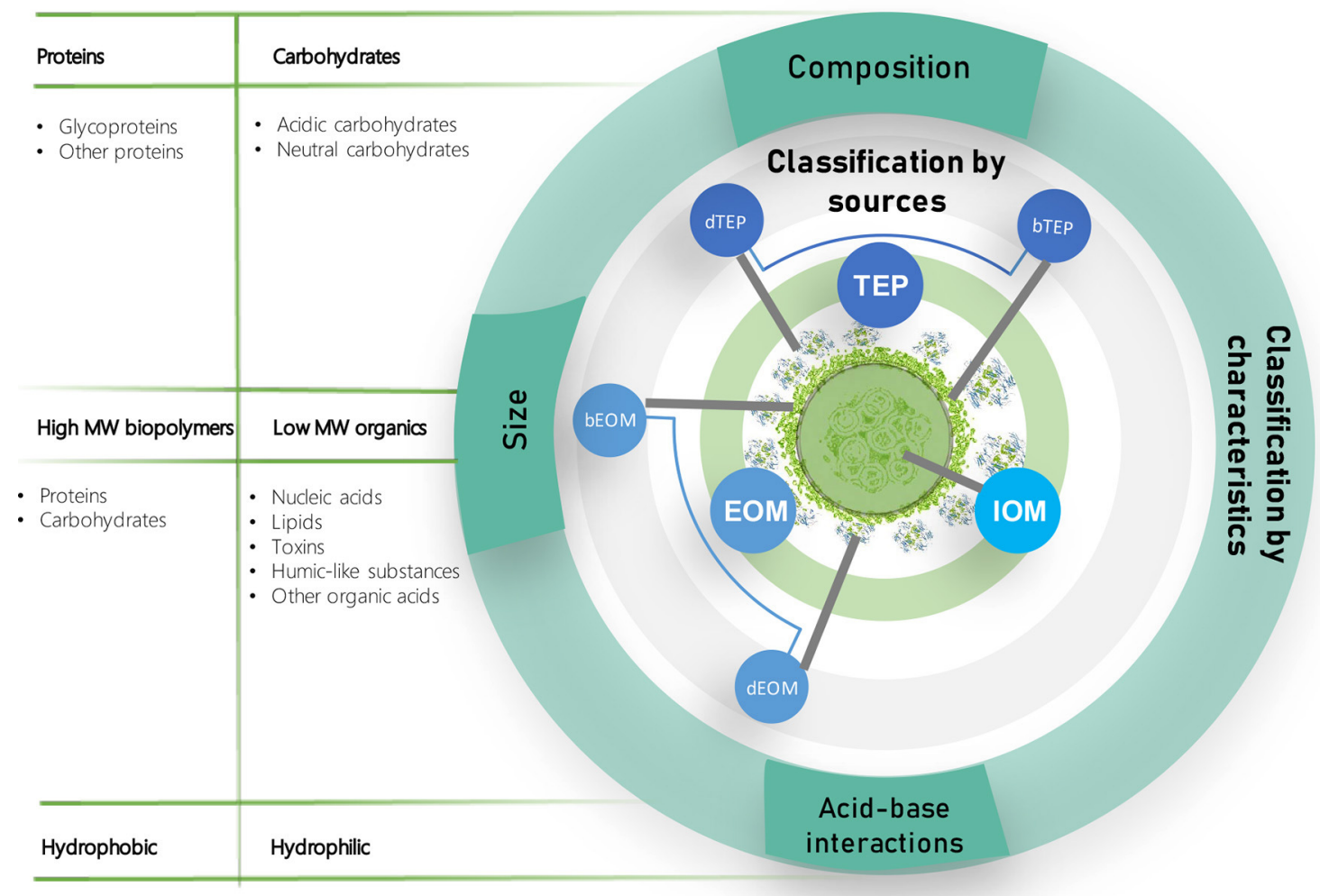

FIGURE 2 | Algal organic matter (AOM) classification according to sources and characteristics. The AOM is considered the main contributor to irreversible fouling in algal membrane separation processes. The AOM can form gel-like structures and irreversibly attach to the membrane pores and surfaces.

for forming stronger intermolecular bridges through hydrogen bonding (Zhang W. et al., 2013; Zhang X. et al., 2013). These interactions increase the adsorption rates and the share of irreversible fouling in the system (Zhang W. et al., 2013; Bin et al., 2017). In contrast, proteins are associated with amino acid chains with hydrophobic side groups that exhibit weak interactions with hydrophilic membranes (Henderson et al., 2008), leading to a loose and reversible fouling (Zhang W. et al., 2013; Zhang et al., 2016; Xu et al., 2018; Zhou et al., 2020). Thereby, proteins have been found to exhibit stronger hydrophobic characteristics compared with carbohydrates, thus with a greater tendency to act as charge neutralizers while forming "gel-like" substances (Henderson et al., 2008; Keyvan Hosseini et al., 2020).

$\mathrm{AOM}$ that results from the algal metabolic activity is termed "external organic matter" (EOM), whereas the internal organic matter (IOM) refers to the AOM released due to cell rupture. The relative fractions of EOM and IOM, as well as size distribution and hydrophobicity, vary depending on the algal growth phase; in logarithmic growth, AOM is mainly composed of EOM as the cells have good integrity and death or lysis does not occur (Bin et al., 2017; Zhou et al., 2020). However, as the biomass reaches a stationary phase, the cell aging and lysis trigger the release of IOM into the solution, increasing drastically the total AOM in solution (Zhuang et al., 2016; Bin et al., 2017; Liu et al.,
2017; Zhang and Fu, 2018). Carbohydrates are reported to be the main component of EOM, whereas the IOM is seemingly richer in proteins (Zhang and $\mathrm{Fu}, 2018$ ). Contradictory results on the impact of carbohydrates and proteins suggest that their effect on membrane fouling is species dependent and relies on the algal growth conditions. Bin et al. (2017) and $\mathrm{Xu}$ et al. (2021) both report the stronger impact of IOM on flux decline (Zhang et al., 2016; Bin et al., 2017), while Low et al. (2016) and Novoa et al. (2020) report a stronger impact of carbohydrates on membrane fouling. However, all the studies highlighted the stronger tendency of EOM to irreversibly deposit onto the membrane surface (Luo et al., 2019). To this extent, strategies targeting the prevention of cell breakage are desired to keep the cell integrity required for the recovery of value-added products (Adhikari and Pellegrino, 2015; Shi et al., 2019).

The fraction of EOM that is dissolved in the algal suspension is named "dissolved EOM" ( $\mathrm{dEOM})$, while the fraction bound to the cell surface is regarded as bound EOM (bEOM). Both dEOM and bEOM are mainly composed of organics with sizes in the high and low fractions $(>100$ and $<1 \mathrm{kDa})$, although dEOM presents a larger share of low-MW organics and greater hydrophilicity (Zhang X. et al., 2013). Qu et al. (2012) reported that dEOM accounted for $80 \%$ of the total EOM of $M$. aureginosa. Thereafter, it remains thoroughly possible to develop operational 
strategies devised to shift the hydrophilicity of $\mathrm{dEOM}$ and to prevent its detachment from algal cells, thus controlling the impact of EOM on irreversible fouling.

By studying the growth of the biofouling layer in the algal bioreactor, Luo et al. (2019) found out that the deposition of foulants across the fouling layers is size dependent. The smallMW organics exhibited high affinity to attach and build upon the membrane surface, while the biopolymers displayed a weak interaction with the membrane surface and, thus, were present at low concentration in the bottom fouling layer $(<10 \%)$. Zhou et al. (2020) confirmed these findings by reporting a preferential deposition of algal cells and debris on the upper cake layer, while larger amounts of organic compounds were contained in the chemically desorbing layer. Furthermore, the lower part of the cake layer of Chlorella vulgaris was found to present a larger amount of proteins, while the carbohydrates were mainly distributed on the upper part of the layer; this is in contrast with another study, reporting larger amounts of carbohydrates on the bottom layer of Arthrospira Platensis (Keyvan Hosseini et al., 2020) and, thereby, support the hypothesis that the distribution of foulants across the cake layer varies among species.

Similar to algal cells, the study of AOM as a fouling precursor needs to be addressed, starting from the inter-foulant interaction with cells and debris (Novoa et al., 2020; Zhang Y. et al., 2020). Therefore, Bin et al. (2017) evaluated the impact of algal cells, debris, EOM, and IOM on the membrane fouling; the relative flux reductions were 10,27 , and $16 \%$ for debris + IOM, cells + EOM, and debris + IOM + EOM, respectively. The authors found out also that the combined algal foulants led to lesssevere adsorptive fouling in comparison with individual foulants, supporting the previous hypothesis of a competitive adsorption of AOM, cells, and debris, and indicating that larger inter-foulant aggregates exert a positive effect on the long-term filterability (Bin et al., 2017; Zhou et al., 2020). Thereby, the cake layer density is determined by the cell-cell interaction, cell-membrane entanglement, and hydrogen bonding interaction between AOM and algal cells (Novoa et al., 2020; Zhang Z. et al., 2020).

\section{Transparent Exopolymer Particles (TEPs)}

A particular case of AOM, termed "transparent exopolymer particles" (TEPs), attracted increasing research due to its significant contribution to membrane fouling. TEPs are characterized by presenting high viscosity, reaching values up to $0.21 \mathrm{~Pa} \bullet$ s (Logan et al., 1995). In fact, TEPs are reported to be about 2-4 orders of magnitude stickier and more flexible than phytoplankton or mineral particles, conferring a gellike structure that significantly increases the probability of attachment upon collision (Bilad et al., 2014; Liao et al., 2018; Zhang Z. et al., 2020). Therefore, TEPs act as an adsorption and condensation nuclei of dissolved fouling precursors, forming aggregates that severely hamper the membrane permeability (Zhang and Fu, 2018; Zhang Z. et al., 2020). Furthermore, upon attachment onto the membrane surface, TEPs act as a scaffold between organisms and the membrane, building a 3D-stable structure that is easily deformed upon the increase in pressure and serves as an ideal surface for the attachment and growth of algae (Zhang Z. et al., 2020).

TEPs and their precursors are generally sticky and highly hydrophilic and comprise mainly of acidic glycoproteins and carbohydrates. TEPs present sizes that range from 0.05 to $200 \mu \mathrm{m}$ (Passow et al., 2001; Berman and Holenberg, 2005; Zhang Z. et al., 2020), and, according to their size, can be classified as colloidal $(0.05-0.4 \mu \mathrm{m})$ and particulate $(>0.4 \mu \mathrm{m})$, although one form converts into the other given certain conditions. Comparably to AOM, the TEPs can also be classified as bound or free TEP $\left({ }_{b}\right.$ TEP and ${ }_{\mathrm{f}}$ TEP), based on its presence in attachment with algal cells or free in solution (Zhang Z. et al., 2020). Zhang Z. et al. (2020) investigated the effect of ${ }_{b}$ TEP and ${ }_{f}$ TEP on UF membrane fouling; $b$ TEP led to a faster flux decline at the beginning of the filtration. However, over time, bTEP reached a maximum plateau level, and ${ }_{\mathrm{f}}$ TEP became the main fouling contributor; $\mathrm{b}$ TEP was found to precede larger reversible fouling than ${ }_{\mathrm{f}}$ TEP (10.8-15.6\% higher), whereas ${ }_{\mathrm{f}}$ TEP was the main factor leading to irreversible fouling ( 37.8 vs. $32.9 \%$ ). Thereupon, the cake layer formed by ${ }_{b}$ TEP was more easily removed by backwash than that formed by $\mathrm{f}$ TEP, and a larger fraction of proteins was found in the latter. Based on the above-described studies, understanding the fraction of TEP in fouling will likely play a more significant role in the development of fouling control strategies in membrane applications in algal technologies.

\section{Combined Effect in Membrane Fouling}

The cake layer permeability is conditioned by the forces acting upon the attachment of algal particles on the membrane (Babel and Takizawa, 2010; Marbelia et al., 2016). In principle, in absence of AOM, the cake resistance increases linearly with the number of cells deposited (Babel and Takizawa, 2010). However, microalgae release AOM and, thus, a dynamic structure are built upon the linkages between algal cells and the AOM, as reported in the literature (Morineau-Thomas et al., 2002; Babel and Takizawa, 2010; Kanchanatip et al., 2016; Zhou et al., 2020). EOM, IOM, and TEP fill void spaces between algal cells and drastically increase the cake resistance (Graphical Abstract). The interactions between algal cells and AOM also determine the size and stability of the algal flocs. To this extent, larger aggregates with homogeneous size distribution are preferred to secure long-term filterability (Bin et al., 2017; Zhou et al., 2020). It is worth noting that the membrane fouling in algal separation processes is governed by several factors (Figure 3).

\section{IMPACT OF MEMBRANES ON ALGAL FOULING}

The membrane proprieties and configuration influence their surface properties and define the dominating fouling mechanism and overall fouling severity (Figure 3). The membrane materials directly impact properties, such as morphology (roughness, pore size, and distribution), hydrophilicity/hydrophobicity and electric charge (Liao et al., 2018; Zhang and Fu, 2018; Mat Nawi et al., 2020). On the other hand, membrane configuration also 


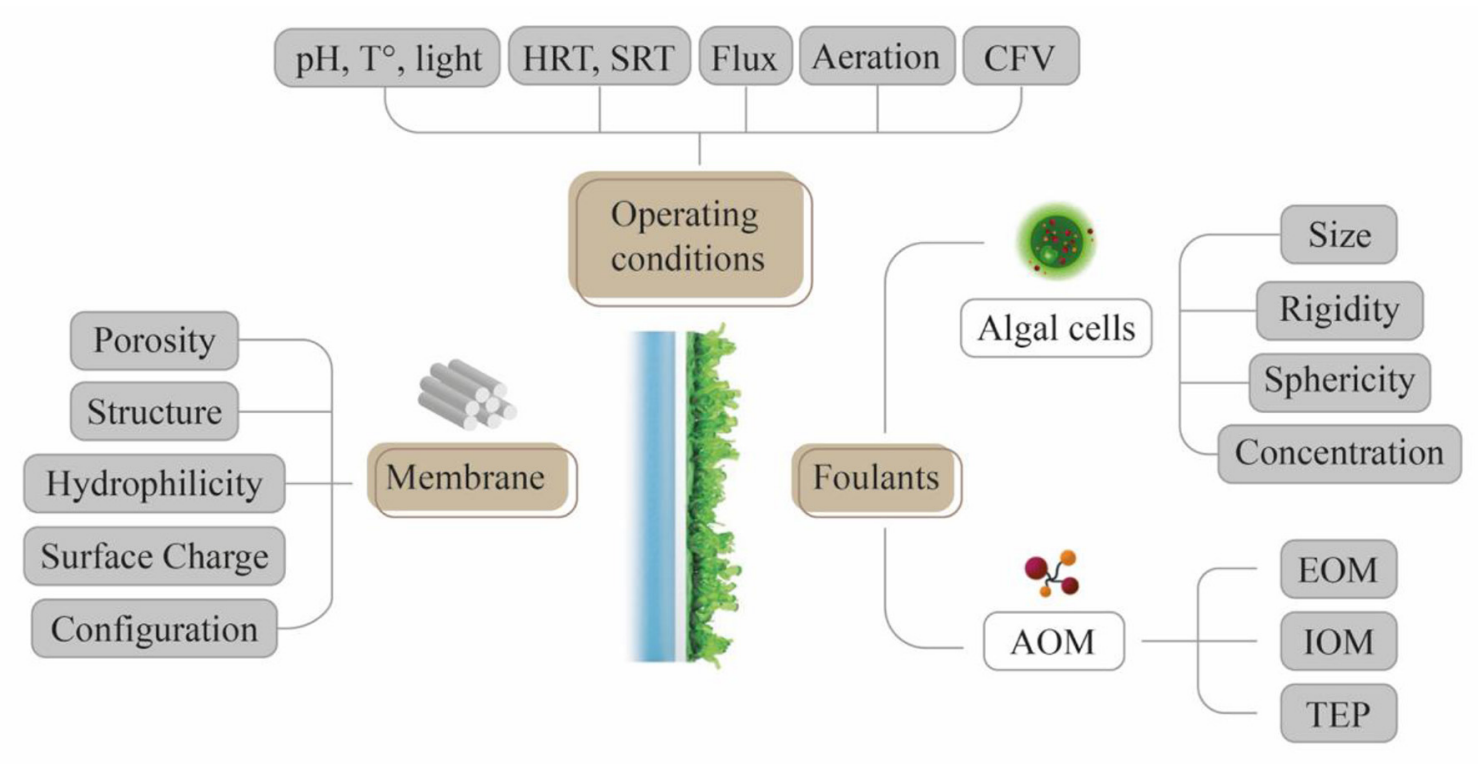

FIGURE 3 | Summary of fouling contributing factors in algal membrane separation processes. The membrane fouling is influenced by the operating conditions, the membrane, the algal species, and AOMs.

impacts the hydrodynamics during permeation and cleaning; for example, hollow-fiber membranes are characterized by higher packing density, allowing higher permeate productivity, albeit increasing the chances of intermembrane clogging and lowering the scouring efficiency during cleaning (Fletcher et al., 2011b; Bagheri and Mirbagheri, 2018; Liao et al., 2018).

\section{Pore Size}

An appropriate membrane pore size is required for an optimal operation, as it determines the retention of algal biomass during harvesting and the dominating fouling mechanism (Liao et al., 2018; Zhang and Fu, 2018; Mat Nawi et al., 2020). The molecular weight distribution of foulants relative to the membrane pore size regulates the fouling propensity, and, thus, the impact of membrane pore size on the fouling development has been widely investigated (Fletcher et al., 2011b; Bilad et al., 2014; Wang et al., 2014; Marbelia et al., 2016; Elcik and Cakmakci, 2017; Krzeminski et al., 2017; Liao et al., 2018; Zhang and Fu, 2018; Zhang Y. et al., 2019). Smaller pores reject a wider range of foulants, increasing the cake layer resistance that can be removed by cleaning techniques such as backwash. Nevertheless, small pores exert higher resistance to water permeation, increasing the energy consumption and creating a trade-off between permeability and fouling control (Fletcher et al., 2011b; Bilad et al., 2014; Wang et al., 2014; Marbelia et al., 2016; Elcik and Cakmakci, 2017; Krzeminski et al., 2017; Liao et al., 2018; Zhang and Fu, 2018; Zhang Y. et al., 2019).

In spite of presenting higher permeate flux, larger pore sizes are more prone to irreversible fouling (i.e., pore-blocking or adsorption) (Low et al., 2016; Liao et al., 2018; Novoa et al., 2020). This was observed by Elcik and Cakmakci (2017) in a comparison between ultrafiltration (UF) and microfiltration
(MF) membranes in cross-flow filtration; larger pore sizes in MF exhibited faster flux decline and presented a higher fouling severity than that of UF membranes. Accordingly, Rickman et al. (2012) compared the filterability properties of UF and MF membranes, using pre-filtered suspensions of Chlamydomonas; MF displayed a higher irreversible fouling propensity, presumably due to the internal pore plugging of submicron particles, while in the UF prevailed the cake layer resistance. In contrast, Zhao et al. (2017) and Bilad et al. (2018) reported the opposite trend: Larger pore sizes resulted in milder fouling and higher permeability, leading to a lower TMP increase. Zhao et al. linked this positive effect to the different drag forces prevailing, as larger pore sizes lowered the hydraulic resistance and reduced the deposition of foulants onto the membrane (Zhao et al., 2017). Contradictory results support the idea that the impact of membrane pore size on fouling development relies on foulant-membrane interactions that are species dependent (Zhang Y. et al., 2019).

\section{Materials and Hydrophobicity/ Hydrophilicity}

Membrane materials used in algal biotechnologies can be classified into organic and inorganic (Zhang Y. et al., 2019). Polymeric organic materials used in membranes include polyvinylidene fluoride (PVDF) (Marbelia et al., 2018), polyacrylonitrile (PAN) (Marbelia et al., 2016), polyethersulfone (PES) (Yogarathinam et al., 2018), cellulose acetate (CA), polyethylene terephthalate (PET) (Kim et al., 2020; Kusumocahyo et al., 2020; Wu and Sancaktar, 2020), polyvinyl alcohol (PVA), regenerated cellulose (RC), polysulfone (PS) (Ma et al., 2020; Zhao et al., 2021a,b), polyamide (PA), and cellulose ester (CE) (Zhang M. et al., 2019). Inorganic materials, such as 
$\mathrm{ZrO}_{2}-\mathrm{TiO}_{2}$, are commonly used in ceramic membranes (Low et al., 2016; Hua et al., 2020). PVDF membranes are widespread in microalgal filtration due to their high thermal and chemical resistance; however, their hydrophobic nature results in poor electrostatic interaction with water molecules and stronger interactions with foulant species (Bilad et al., 2018; Marbelia et al., 2018). On the other hand, hydrophilic membranes exhibit a higher anti-fouling capacity with respect to hydrophobic membranes, owing to a reduced adsorption of hydrophobic protein-like substances and dissolved macromolecular compounds (Liao et al., 2018; Marbelia et al., 2018; Zhang Y. et al., 2019). However, the low mechanical resistance of hydrophilic membranes hinders their widespread application (Bilad et al., 2014; Liao et al., 2018; Mat Nawi et al., 2020). Different materials exhibit differences in surface charge and hydrophobicity/hydrophilicity; thereby, surface modification techniques, such as coatings and grafting, have been employed to develop robust and fouling-resistant membranes (Marbelia et al., 2018).

The use of hydrophilic materials, such as nanofiber membranes, has been increased over the last years due to their efficiency in microalgae harvesting, although their mechanical strength still represents a bottleneck (Liao et al., 2018; Marbelia et al., 2018; Zhang Y. et al., 2019; Mat Nawi et al., 2020). Accordingly, Mat Nawi et al. (2020) investigated the applicability of electrospinning mechanically enhanced nylon 6.6 nanofiber membranes (NFM) in algal filtration. The crossing and overlapping of NFM fibers reduced thickness, porosity, and mean pore size by 18,4 , and $40 \%$, respectively, the effect, created by the fusion and melting of fibers, increased the mechanical resistance of the membrane by more than 2 -fold (221\%). Additionally, the surface modification reduced surface roughness and water contact angle by 63 and $28 \%$, respectively, increasing the overall membrane hydrophilicity (Mat Nawi et al., 2020). Similarly, Bilad et al. (2018) compared the performance of nylon 6.6 nanofiber membrane (NFM) with a PVDF phase inverted membrane (PVDF-PIM) for filtration of Chlorella vulgaris; Nylon 6.6 NFM was found to have higher permeability (1,018 vs. $493 \mathrm{~L} / \mathrm{m}^{2}$.h) and better fouling resistance than PVDF-PIM. This was attributed to the lower contact angle $(0.25$ vs. 76$)$, the larger pore size $(0.12$ vs. $0.09 \mu \mathrm{m})$, and a higher surface porosity (25.82 vs. $18.84 \%$ ), compared with PVDF-PIM. Moreover, it is worth mentioning that lowering the surface roughness is targeted in membrane design to control the fouling deposition and, more importantly, to lower the water contact angle and enhance the membrane hydrophilicity (Liao et al., 2018; Mat Nawi et al., 2020).

Recent studies have explored the use of PET-based membranes due to their commercial availability, low price, and stability (Kusumocahyo et al., 2020; Wu and Sancaktar, 2020). Kim et al. (2020) used an anthracene (ANT)-attached polyethylene glycol (PEG) surface-modification agent to create a hydration layer by coating the surface with brush and arch forms. The resulting hydrolyzed membrane exhibited an improved antifouling effect and microalgal productivity compared with the unmodified one. Analogously, Marbelia et al. (2018) used PVP cross-linking modification and sulfonation to enhance the hydrophilicity and antifouling properties of PVDF membranes; the water permeability and fouling resistance increased by PVP modification in four different algal species (Danuliella, Picochlorum, Scenedesmus, and Diacronema), indicating the efficiency of hydrolyzed membranes as a fouling control strategy in algal separation. Recently, PET self-forming dynamic membranes have been proposed in an innovative photobioreactor, allowing harvesting biomass at rates of 41 $\mathrm{g} / \mathrm{m}^{2} 2021$ (Senatore et al., 2021).

\section{Electric Surface Charge}

In addition to hydrophilicity, surface charge and electrostatic interactions play significant roles in the membrane fouling potential. Negatively charged hydrophilic membranes are reported to enhance the electrostatic repulsion with negatively charged AOM and algal cells, inducing an antifouling effect on the membrane surface (Liao et al., 2018; Marbelia et al., 2018). Accordingly, Marbelia et al. (2016) evaluated the filterability of different microalgae species when using hydrolyzed negatively charged PAN-based membranes. For most species, negatively charged membranes mitigated the fouling development during the first $120 \mathrm{~min}$ of filtration. However, thereupon, the antifouling effect faded, indicating that the electrostatic repulsion forces become less significant over time, as hydrodynamic interactions become the main parameter, controlling fouling development. Similarly, applying direct currents $(\mathrm{dc})$ to conducting materials allowed to successfully remove organics and mitigate membrane fouling in electrochemically reactive ceramic membranes made of $\mathrm{TiO}_{2}$ (Hua et al., 2020); the antifouling effect was tested at different dc $\left(-1.25\right.$ to $\left.+2.5 \mathrm{~mA} . \mathrm{cm}^{-2}\right)$, proving to be efficient at mitigating membrane fouling and maintaining higher critical flux when using positive currents. The effect was ascribed to radical electrostatic repulsion and formation of microbubbles on the membrane surface.

\section{IMPACT OF OPERATING CONDITIONS}

\section{Environmental Conditions (pH, Temperature, and Light)}

Environmental conditions, such as $\mathrm{pH}$, temperature, and light, significantly impact the fouling severity by influencing the algal growth, the AOM, and the cell surfaces. The $\mathrm{pH}$ influences the degree of protonation/deprotonation and, thus, the surface charge in algal foulants and the electrostatic repulsive/attractive interactions with the membrane; lower $\mathrm{pH}$ values create positive surface charges by increasing the concentration of amine groups, whereas, at high $\mathrm{pH}$, these groups are deprotonated, inducing a net negative surface charge (Zhou et al., 2014; Zhang and $\mathrm{Fu}, 2018)$. Comparatively, under acidic conditions, the repulsive interactions between TEP and UF membranes significantly decreased $(41.7 \%)$ in comparison with neutral and alkaline conditions, facilitating the adhesion of free TEPs onto the membrane and, thereby, increasing the irreversible membrane fouling (Zhang Z. et al., 2020).

The pH-dependent surface charges exert a direct effect on the floc properties and coagulation efficiency (Zhou et al., 2014; 
$\mathrm{Xu}$ et al., 2021). As reported by Zhou et al. (2014), the low $\mathrm{pH}$ intensifies the interactions between the EOM and the membrane surface, thus increasing the membrane fouling. Analogously, $\mathrm{Xu}$ et al. (2021) evaluated the impact of $\mathrm{pH}$ on coagulation; the results highlighted the effect of the $\mathrm{pH}$ on the isoelectric point $\left(\mathrm{pH}_{\mathrm{iep}}\right)$ of different coagulants, impacting the floc size and formation rate and, subsequently, the cake layer filterability. Acidic conditions favored the isoelectric point of a titanium xerogel coagulant, enabling the aggregation of algae and organic matter upon dosing; alkaline conditions, on the other hand, proved to be inadequate for achieving charge neutrality, and, thereby, the aggregation was lower. Finally, it is worth noting that increases in the $\mathrm{pH}$ associated with algal photosynthesis increased the formation of mineral foulants and, thereby, the inorganic fouling resulting from the precipitation of phosphorus, calcium, and iron (Hu et al., 2015).

Light and temperature affect the enzymatic activity of microalgae and the diffusivity of organic matter (Liao et al., 2018; González-Camejo et al., 2019). The increase in temperature reduces the water viscosity and increases the membrane permeability; thereafter, the drag forces toward the membrane are weakened, and the deposition of microalgal cells is reduced (Zhao et al., 2015; Liao et al., 2018). Furthermore, the temperature influences the enzymatic activity, impacting the AOM production (Liao et al., 2018). In fact, Zhao et al. (2015) observed a decrease in the secretion of EOM by increasing the temperature from 15 to $30^{\circ} \mathrm{C}$. On the other hand, the light influences also microalgal productivity and death and lysis of the algal cells. Furthermore, variations in the light/dark cycles can induce a cell lysis and, thereby, increase the IOM concentration in solution (González-Camejo et al., 2019). A photoinhibition effect was found at light intensities beyond $1,800 \mu \mathrm{mol} . \mathrm{m}^{-2} \mathrm{~s}^{-1}$ (González-Camejo et al., 2019).

Based on the notions described above, it is reasonable to secure environmental conditions that assure cell integrity while favoring charge neutrality and aggregation. Further to this, adjusting light cycles/intensity and $\mathrm{pH}$ results challenging in the long-term operation, as it directly impacts the algal biomass quality.

\section{Nutrients, Hydraulic Retention Time (HRT), and Solids Retention Time (SRT)}

In terms of nutrients, the food to the microorganism ratio (F/M) relates to the substrate provided per unit of volume of algae (Metcalf and Eddy, 2003). At low F/M ratios, algal flocs are characterized by compact arrangements that are characterized by high stability (Barbusiński and Kościelniak, 1995; Medina and Neis, 2007). While, at high F/M ratios, the flocs exhibit a high propensity to break up and, thereby, resulting in a heterogenous size distribution of floc aggregates (Barbusiński and Kościelniak, 1995; Medina and Neis, 2007; Ashadullah et al., 2021). This effect was investigated by Novoa et al. (2020), reporting fewer stable aggregates and a broader particle size distribution when higher nutrients were supplied at shorter HRT; the resulting cake layer formed on the membrane surface consisted of heterogeneous particles, and, thus, the void spaces between large particles were filled by the smaller ones, lowering the cake porosity and increasing its resistance to permeation. The results are in agreement with the reported effect of F/M in conventional MBRs (Liao et al., 2002, Wu et al., 2013); for example, higher F/M ratios were reported by Ashadullah et al. (2021) and Wu et al. (2013) to induce a larger surplus of the substrate that triggered the excretion of EPS, while, on the other hand, low F/M ratios decreased the bacterial growth rates, increasing endogenous metabolism and cell lysis (Metcalf and Eddy, 2003; Fletcher et al., 2011b; Zhang M. et al., 2020).

The F/M ratio is directly affected by parameters such as the HRT and SRT, which refer, respectively, to the residency time of feed solution and the microalgal biomass in the reactor. The HRT directly impacts the loading rate of nutrients into the reactor, whereas an upsurge in nutrients is observed at lower HRT. The SRT impacts the retention time of the algal biomass in the reactor, and, thereby, lower SRT limits the contact time between algae and nutrients, lowering the uptake of nutrients needed for metabolic growth. On the other hand, higher biomass retention times at longer SRTs might result in greater biomass concentrations, as the nutrients are efficiently removed from the feed at a constant HRT (Metcalf and Eddy, 2003; Fletcher et al., 2011b; Ashadullah et al., 2021; Zhang M. et al., 2020).

The impacts of HRT and SRT directly affect the metabolic growth and, thereby, the fouling mechanisms and overall severity. Novoa et al. (2020) assessed the fouling behavior of Chlorella vulgaris cultivated in an MPBR at HRTs of 12, 24, and $36 \mathrm{~h}$; higher nutrient loading at $\mathrm{HRT}_{12 \mathrm{~h}}$ impacted the PSD and the AOM production, leading to the formation of a dense cake layer on the membrane surface. On the other hand, a longer HRT $\left(\mathrm{HRT}_{24 \mathrm{~h}}\right.$ and $\left.\mathrm{HRT}_{36 \mathrm{~h}}\right)$ resulted in a narrower PSD, leading to a more moderate fouling and stable flux. Similarly, Low et al. (2016) reported an increase in the average particle size from 8.5 to $13.1 \mu \mathrm{m}$, when the HRT was reduced from 72 to $6.5 \mathrm{~h}$. The decrease in HRT was followed by the increase of the biopolymer concentrations and by the formation of large and heterogenous aggregates in the reactor, leading to the development of a dense cake layer with higher hydraulic resistance. Moreover, the longer $\mathrm{HRT}_{72 \mathrm{~h}}$ enhanced the hydrolysis of the organic molecules into low MW compounds, responsible for a milder and yet more irreversible fouling, compared with a high MW compound (i.e., biopolymers).

The impact of the N/P ratio and nutrient depletion conditions on the filtration performance has been evaluated by several authors (Huang et al., 2012; Zevin et al., 2015; Zhang M. et al., 2020). Zhang Z. et al. (2020) evaluated the effects of the HRT and N/P ratio on fouling propensity. At the same N/P ratio, shorter HRTs led to severe fouling. Conversely, at equal HRTs, lower N/P ratios (3.9:1) showed smaller floc sizes and faster fouling rates compared with higher ratios (9.7:1). Huang et al. (2012) reported an increase of the hydrophilic fraction at a lower $\mathrm{N} / \mathrm{P}$ ratio $(1: 10)$ in discrepancy with higher ratios (1:2 and 1:1). Similarly, Zevin et al. (2015) analyzed the SMP in two PBRs, cultured with Synechocystis sp., operated under normal $\left(\mathrm{PBR}_{\mathrm{P}+}\right)$ and limited phosphate $\left(\mathrm{PRB}_{\mathrm{P} 0}\right)$ conditions. $\mathrm{PBR}_{\mathrm{P}+}$ led to greater biomass production while lowering the SMP production per unit of biomass, compared with $\mathrm{PBR}_{\mathrm{P} 0}$. The latter 
exhibited a larger concentration of carbohydrates due to the phosphate limitation.

Based on the results reported in the literature, it might be desired to target high N/P ratios and longer HRTs. However, the extreme nutrient limitation might result in the breakup of large biopolymers into small-MW organics and into the endogenic release of IOM, resulting from a cell lysis, increasing the fouling potential. Conversely, short HRTs and, thereby, high-nutrient loading rates result in faster metabolic growth, whereas the EOM fraction prevails over irreversible IOM. In summary, the balance between the nutrient-loading rates and the residence time of algal biomass determines the concentration of the IOM/EOM in the membrane reactor.

\section{Flux and Hydrodynamic Conditions}

The hydrodynamic conditions in algal membrane processes are governed by several factors, including flux, cross-flow velocity and air scouring. These parameters impact the fouling behavior, as they exert great influence on the algal cell deposition rates, cell integrity, and permeate drag forces. A conventional approach to mitigate the fouling in the system consists of reducing the permeate drag force by applying mild flux and increasing the shear (Zhang and Fu, 2018; Bamba et al., 2021).

When operating at constant flux, the deposition of fouling on the membrane surface leads to a significant increase of the transmembrane pressure (TMP) required to achieve constant flux production (Liao et al., 2018; Zhang and Fu, 2018). An alternative strategy consists of operating under subcritical flux conditions to decrease the convective forces that drag the foulants toward the membrane. However, although reducing the permeate flow rate can be used to mitigate the fouling developed on the membrane, it significantly impacts the capital cost by requiring larger membrane areas (Fletcher et al., 2011b). Wu et al. (2018), compared the filtration performance of Chlorella vulgaris under sub and supercritical flux conditions (22 and 44 $\mathrm{LMH}$, respectively); as expected, the subcritical flux displayed a more stable filtration performance and lower irreversible fouling (7 vs. 10\%) compared with supercritical flux conditions. The latter displayed larger resistance (61\% higher), thereby exhibiting a higher overall contribution to fouling (9.2 vs. $2 \%$ ). Analogously, similar results are reported by Kanchanatip et al. when characterizing the flux decline of Arthrospira maxima; the results confirm that higher permeate velocity increases the particle's deposition rates on the membrane surface (Kanchanatip et al., 2016).

Another parameter that affects the filtration performance is the fluid cross-flow velocity (CFV). The CFV is directly linked to the turbulence and shear force and, thereby, allows to decrease the accumulation of microalgae on the membrane, achieving higher filtration flux (Elcik and Cakmakci, 2017; Liao et al., 2018; Bamba et al., 2021). Elcik and Cakmakci (2017) evaluated the microalgal harvesting at different CFVs. At a TMP of a 1.5 bar, cross-flow velocities of 0.35 and $1.57 \mathrm{~m} / \mathrm{s}$ led to fluxes of 65 and $195 \mathrm{LMH}$, respectively, demonstrating that increasing the CFV is associated with enhanced filtration flux, as it was thereafter confirmed by Bamba et al. (2021) in ceramic microfiltration of Chlorella vulgaris and Tisochrysis lutea. Similarly, Ozkan and
Berberoglu reported that, at a flow rate of $1 \mathrm{ml} \mathrm{min}{ }^{-1}$, the net force acting on a cell adhered over a substratum, decreased from $1.9 \times 10^{-11}$ to $3.3 \times 10^{-12} \mathrm{~N}$ as the effective cell diameter interacting with the membrane decreased from 10.4 to $4.3 \mu \mathrm{m}$. At a velocity of $1.5 \mathrm{~mm} \mathrm{~s}^{-1}$, the kinetic energy of Chlorella vulgaris increased to counter the attractive energy between cells and a substratum, thus preventing the attachment on the surface (Ozkan and Berberoglu, 2013). It is worth to mention that there is a critical CFV that negatively impacts the cell integrity and the transmission of AOM across the membrane after being overpassed (Wicaksana et al., 2012; Ozkan and Berberoglu, 2013). This effect was observed for CFV values above $0.17 \mathrm{~m} / \mathrm{s}$ (Wicaksana et al., 2012).

\section{MEMBRANE CLEANING}

As membrane fouling exacerbates, the need of frequent membrane cleaning to keep constant flux becomes a major challenge as it reduces the efficiency of algae harvesting and permeate flux and reduces the lifetime of the membranes (Zhao et al., 2018). Thereby, choosing an adequate membrane cleaning mechanism is of vital importance in terms of energy consumption, permeate production, and overall process performance (Zhao et al., 2018; Fortunato et al., 2020).

Cleaning strategies, namely backwash, relaxation, and air scouring, are commonly employed in the operation of a submerged reactor, displaying different effects on fouling control. The relaxation temporary stops the filtration, thus allowing the release of foulants from the cake layer into the solution via back transport (Mat Nawi et al., 2020); backwash, on the other hand, consists of reversing the permeate flow, allowing the partial detachment of the fouling layer and the removal of the particles attached to the membrane surface, thereby reducing the compaction of the gel polarization layer and alleviating the fouling caused by pore blockage and cake formation (Fletcher et al., 2011b; Wang et al., 2014; Bagheri and Mirbagheri, 2018); finally, air scouring employs gas bubbles that move across the membrane surface, resulting in localized shear stress conditions that scour the foulants attached on the outer fouling layer and promote a turbulent flow regime that facilitates their back transport into the solution (Mat Nawi et al., 2020).

Fortunato et al. (2020) investigated the impact of membrane cleaning techniques by monitoring the algal biomass morphology developed on the membrane surface under continuous operation. The use of relaxation led to a thicker and more porous algal cake that, in turn, displayed better filterability properties and lower energy consumption compared with backwash (Figure 4). Membrane cleaning techniques present, however, some drawbacks; long relaxation periods reduce the filtration time, hampering the permeate productivity (Fortunato et al., 2020). The impact on productivity is even more severe in backwash, as large backwash flow rates are reportedly required to remove strongly attached LMW organics, thus diminishing significantly the permeate produced and exerting extra energy inputs, analogous to the one caused by the large energy demands of air scouring (Fortunato et al., 2020; Mat Nawi et al., 2020). 

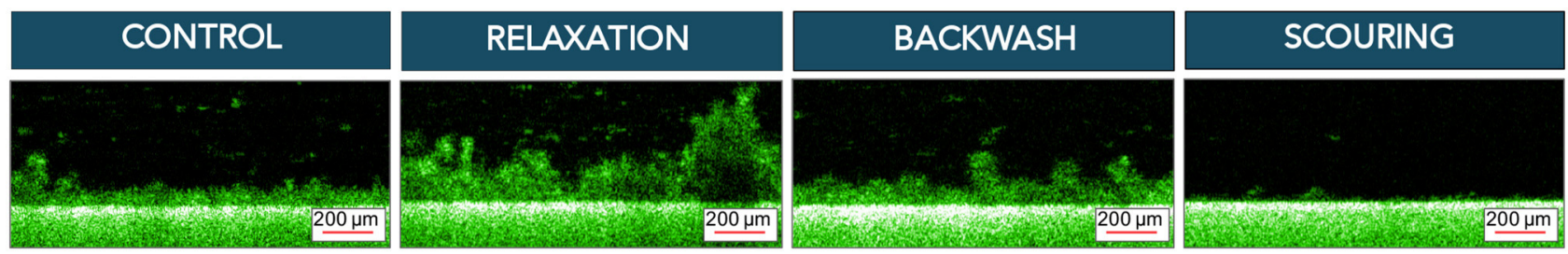

FIGURE 4 | Algae biomass morphology developed on the membrane surface under different fouling cleaning strategies in submerged algae membrane photobioreactor. The biomass morphology was monitored non-destructively in-situ with optical coherence tomography (OCT), adapted from Fortunato et al. (2020).

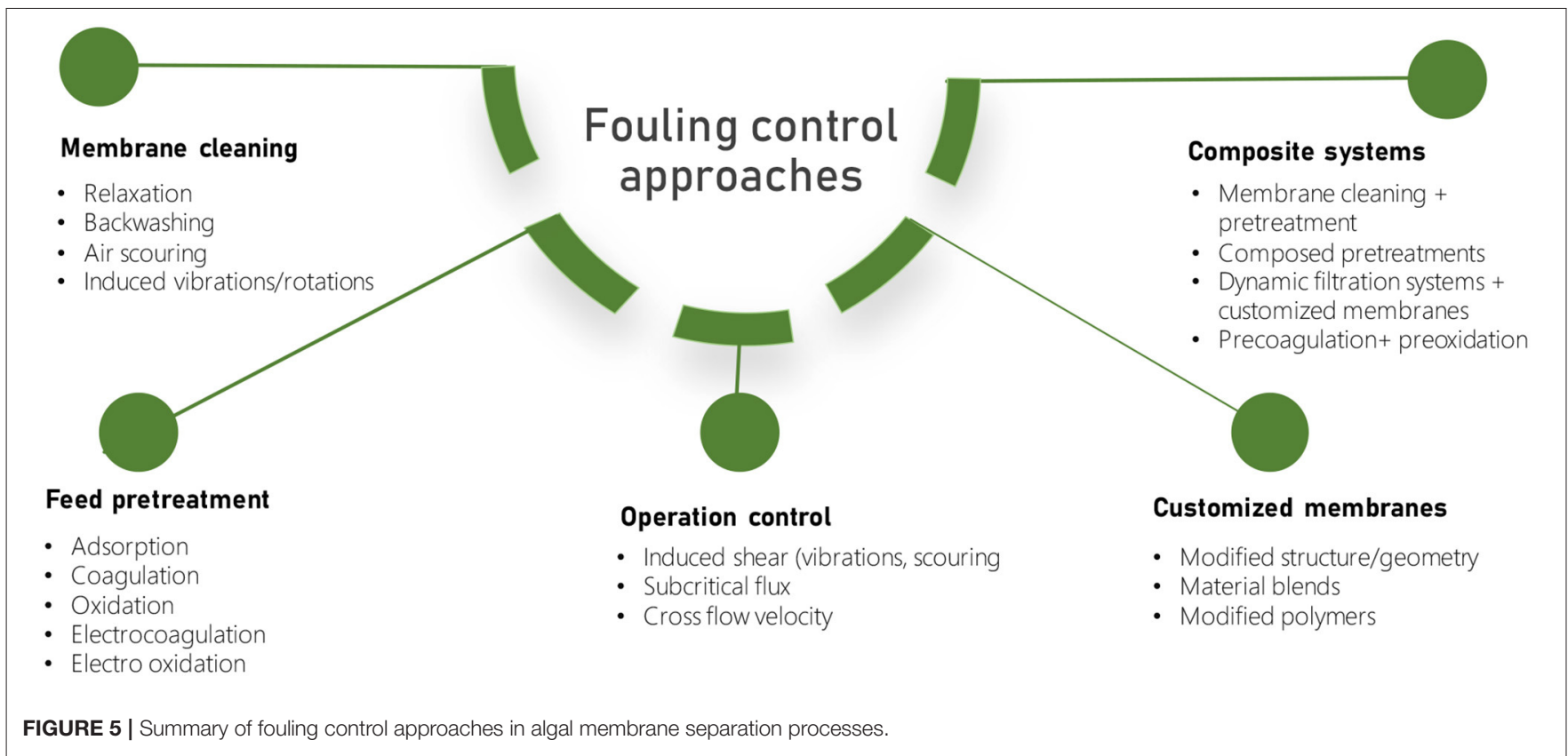

Therefore, a porous and permeable cake layer is reportedly preferred in operation, owing its effect of sieving irreversible foulants. The effect of air scouring beyond a shear threshold limits the cake thickness and, in turn, increases the severity of irreversible fouling caused by LMW-organics that directly interact with the membrane (Fortunato et al., 2020; Mat Nawi et al., 2020).

Recent developments have aimed to optimize the shear effect created by air scouring systems. Eliseus et al. (2017) designed a customized tilted membrane panel that maximized the local shear and lift forces created by air bubbles during air scouring for filtering Euglena sp.; the permeability was improved by $20-30 \%$ as the tilting angle was increased up to $20^{\circ}$, maximizing the contact between air bubbles and the membrane surface (Eliseus et al., 2017). Accordingly, Mat Nawi et al. (2020) tilted the panel of nanofiber membranes to $20^{\circ}$ to improve the fouling control effect of membrane cleaning cycles; increasing the aeration rates enhanced the permeability up to $379 \mathrm{LMH}$.

Emerging cleaning strategies attempt to reduce the area wherein shear stress is applied (Bamba et al., 2021; Zhao et al., 2021b). This effect has proved to be efficient at controlling fouling, while securing cell integrity and thus limiting the release of irreversible foulants. For example, dynamic filtration systems apply a relative motion, either by vibration or rotation, in the membrane-foulant interface within the range of $0-0.5 \mathrm{~mm}$ of distance, and, thereby, the algal cells in the feed are protected from shear-induced damage, while the shear is efficiently applied on the cake layer and concentration polarization layers (Zhang and Fu, 2018; Jiang et al., 2020).

\section{DEVELOPMENTS AND CHALLENGES OF ALGAL FOULING CONTROL}

The study of the dynamic interactions involved at the membranefoulant interface led to the developments of several algal fouling control strategies (Figure 5, Table 2). Most of the strategies were initially adopted from other membrane filtration processes (i.e., MBR for wastewater treatment). However, there are fundamental differences between bacterial and algal processes. For example, in the activated sludge MBRs, the main focus is the removal of pollutants and the recovery of clean permeate. In contrast, in algal membrane-based processes, one of the main objectives is the recovery of valuable algal biomass (Deng et al., 2016; Liao et al., 
TABLE 2 | Summary of recent findings on algal fouling precursors and their effect on fouling development.

\begin{tabular}{|c|c|c|c|c|}
\hline Algal species & $\begin{array}{l}\text { Foulants } \\
\text { of interest }\end{array}$ & Membrane characteristics & Main findings & References \\
\hline $\begin{array}{l}\text { Chlorella vulgaris } \\
\text { C. reinhardtii }\end{array}$ & Algal cells & $\begin{array}{l}\text { Submerged hollow fiber } \\
\text { Polypropylene } \\
0.1 \mu \mathrm{m} \mathrm{MF}\end{array}$ & $\uparrow$ cell size $\rightarrow \uparrow$ cake resistance & Shekhar et al., 2017 \\
\hline $\begin{array}{l}\text { Tetraselmis suecica, } \\
\text { Phaeodactylum tricornutum, } \\
\text { Isochrysis galbana, } \\
\text { Diacronemalutheri, Chlorella } \\
\text { vulgaris, Chlamydomonas } \\
\text { reinhardtii, Scenedesmus obliquus, } \\
\text { and Pseudanabaena }\end{array}$ & Algal cells & $\begin{array}{l}\text { Submerged flat sheet } \\
\text { Polyacrylonitrile (PAN) } \\
15,000 \mathrm{~g} / \mathrm{mol} \mathrm{MW}\end{array}$ & $\begin{array}{l}(\uparrow \text { cell size }+\uparrow \text { sphericity }+ \text { narrow PSD }) \rightarrow \uparrow \\
\text { filterability }\end{array}$ & Marbelia et al., 2016 \\
\hline $\begin{array}{l}\text { Chlorella vulgaris, Phaeodactylum } \\
\text { tricornutum }\end{array}$ & Algal cells & $\begin{array}{l}\text { Submerged flat sheet } \\
\text { 9-12\% W/W PVDF } \\
\text { 0.013-0.036 } \mu \mathrm{m} \text { MF }\end{array}$ & ( $\uparrow$ cell rigidity $+\uparrow$ sphericity) $\rightarrow \uparrow$ filterability & Bilad et al., 2018 \\
\hline $\begin{array}{l}\text { N. oculata, Isochrysis, Chlorella } \\
\text { vulgaris, Phaeodactylum } \\
\text { tricornutum, Pavlova lutheri, } \\
\text { Nannochloropsis oculate }\end{array}$ & Algal cells & $\begin{array}{l}\text { Submerged flat sheet } \\
\text { PVC, PES, PVDF } \\
0.01-0.04 \mu \mathrm{m} \text { MF }\end{array}$ & $\begin{array}{l}\text { ( } \uparrow \text { cell rigidity }+\uparrow \text { sphericity) } \rightarrow \uparrow \text { filterability } \\
\uparrow \text { cell flexibility } \rightarrow \uparrow \mathrm{TMP} \text { jumps } \rightarrow \downarrow \text { filterability }\end{array}$ & $\begin{array}{l}\text { Baerdemaeker et al., } \\
2013\end{array}$ \\
\hline Arthrospira maxima & $\begin{array}{l}\text { Algal cells, } \\
\text { AOM }\end{array}$ & $\begin{array}{l}\text { Submerged circular-disc } \\
\text { PVDF } \\
\text { 10-80 nm UF }\end{array}$ & $\begin{array}{l}\text { Cells are the primary foulants in a cake layer } \\
\text { Biopolymers and macromolecules only contributed to } \\
\text { reversible fouling } \\
\text { AOM displayed minor contribution to fouling resistance } \\
\uparrow \text { cell concentration } \rightarrow \uparrow \text { chances of coagulation } \rightarrow \uparrow \\
\text { cake layer resistance }\end{array}$ & $\begin{array}{l}\text { Kanchanatip et al., } \\
2016\end{array}$ \\
\hline Chlorella sp. & $\begin{array}{l}\text { Algal cells, } \\
\text { AOM }\end{array}$ & $\begin{array}{l}\text { Cross-flow flat sheet } \\
0.45 \mu \mathrm{m} \mathrm{MF}\end{array}$ & $\begin{array}{l}\uparrow \text { cell concentration }+\uparrow \mathrm{AOM} \rightarrow \uparrow \uparrow \text { cake layer } \\
\text { resistance } \\
\uparrow \text { cell concentration } \rightarrow \uparrow \text { cake layer resistance }\end{array}$ & Javadi et al., 2014 \\
\hline Chlorella sp. & $\begin{array}{l}\text { Algal cells, } \\
\text { AOM }\end{array}$ & $\begin{array}{l}\text { Batch-submerged flat sheet } \\
\text { PVDF } 0.45 \mu \mathrm{m}\end{array}$ & $\begin{array}{l}\uparrow \text { cell concentration }+\uparrow \mathrm{AOM} \rightarrow \uparrow \uparrow \text { cake layer } \\
\text { resistance } \\
\uparrow \text { cell concentration } \rightarrow \uparrow \text { cake layer resistance } \\
\uparrow \mathrm{EOM} \rightarrow \downarrow \text { interparticle resistance } \rightarrow \uparrow \text { cake } \\
\text { compressibility }\end{array}$ & $\begin{array}{l}\text { Babel and Takizawa, } \\
2010\end{array}$ \\
\hline Chlorella & $\begin{array}{l}\text { Algal cells, } \\
\text { AOM } \\
\text { (dissolved } \\
\text { EOM, } \\
\text { bond } \\
\text { EOM, and } \\
\text { IOM) }\end{array}$ & $\begin{array}{l}\text { Submerged flat sheet } \\
\text { Hollow fiber hydrophilic PVC } \\
50 \text { kDa MW }\end{array}$ & $\begin{array}{l}\text { DOM was the main fouling precursor } \\
\uparrow \mathrm{DOM} \rightarrow \uparrow \text { irreversible fouling } \\
\mathrm{dEOM}: \uparrow \text { low-MW organics and } \uparrow \text { hydrophilicity } \\
\uparrow \text { hydrophilic carbohydrates } \rightarrow \uparrow \text { strength of } \\
\text { attachment } \\
\uparrow \text { hydrophobic proteins } \rightarrow \downarrow \text { attachment to membrane } \\
\downarrow \mathrm{MW} \text { of DOM } \rightarrow \uparrow \text { flux decline }\end{array}$ & $\begin{array}{l}\text { Zhang W. et al., } \\
2013\end{array}$ \\
\hline Microcystis aeruginosa & $\begin{array}{l}\text { Algal cells, } \\
\text { debris, } \\
\text { EOM, and } \\
\text { IOM }\end{array}$ & $\begin{array}{l}\text { PVDF UF cell } \\
60 \mathrm{kDa} \mathrm{MW}\end{array}$ & $\begin{array}{l}\uparrow \text { algal cells } \rightarrow \uparrow \uparrow \text { reversible flux decline } \\
\uparrow \text { algal debris and IOM } \rightarrow \uparrow \text { irreversible flux decline } \\
\uparrow \mathrm{AOM} \rightarrow \downarrow \text { cake porosity } \rightarrow \downarrow \text { filterability }\end{array}$ & Bin et al., 2017 \\
\hline $\begin{array}{l}\text { Chlorella vulgaris, Microcystis } \\
\text { aeruginosa, Asterionella formosa, } \\
\text { and Melosira sp. }\end{array}$ & $\mathrm{AOM}$ & - & $\begin{array}{l}\uparrow \text { proteins } \rightarrow \uparrow \text { hydrophobicity } \rightarrow \uparrow \text { gel-like } \\
\text { substances } \\
\uparrow \text { hydrophobicity } \rightarrow \downarrow \text { charge density }\end{array}$ & $\begin{array}{l}\text { Henderson et al., } \\
2008\end{array}$ \\
\hline Microcystis aeruginosa & $\begin{array}{l}\text { Algal cells, } \\
\text { AOM }\end{array}$ & $\begin{array}{l}\text { Batch-submerged } \\
\text { PVDF flat sheet UF }\end{array}$ & $\begin{array}{l}\uparrow \text { cells and EOM } \rightarrow \uparrow \text { reversible resistance } \\
\uparrow \text { shear } \rightarrow \uparrow \text { cell breakdown } \rightarrow \uparrow \mathrm{IOM} \rightarrow \uparrow \\
\text { irreversible fouling } \\
\uparrow \text { reversible resistance } \rightarrow \uparrow \mathrm{AOM} \text { removal } \\
\text { Reversible fouling was the main fouling contributor }\end{array}$ & Liu et al., 2017 \\
\hline Microcystis aeruginosa & $\begin{array}{l}\text { Dissolved } \\
\text { and bond } \\
\text { EOM }\end{array}$ & $\begin{array}{l}\text { Polyethersulfone (PES) FS } \\
100 \text { kDa MW }\end{array}$ & $\begin{array}{l}\text { dEOM: polysaccharides, humics and }++ \text { proteins } \\
\mathrm{dEOM}: \uparrow \text { hydrophilicity } \rightarrow \uparrow \uparrow \text { fouling rates and } \uparrow \\
\text { reversible fouling } \\
\text { bEOM: proteins and }++ \text { polysaccharides } \\
\text { bEOM = slow fouling rates and } \uparrow \text { irreversible fouling }\end{array}$ & Qu et al., 2012 \\
\hline Chlorella vulgaris & $\mathrm{AOM}$ & $\begin{array}{l}\text { Submerged PVDF } \\
\text { Flat sheet } \\
0.04 \mu \mathrm{m} \mathrm{MF}\end{array}$ & $\begin{array}{l}\text { Large biopolymers } \rightarrow \uparrow \text { membrane rejection } \rightarrow \uparrow \text { cake } \\
\text { layer resistance } \\
\text { Small MW organics } \rightarrow \downarrow \text { cake rejection } \rightarrow \uparrow \\
\text { irreversible fouling in a gel layer }\end{array}$ & Luo et al., 2019 \\
\hline
\end{tabular}


TABLE 2 | Continued

\begin{tabular}{|c|c|c|c|c|}
\hline Algal species & $\begin{array}{l}\text { Foulants } \\
\text { of interest }\end{array}$ & Membrane characteristics & Main findings & References \\
\hline $\begin{array}{l}\text { Chlorella vulgaris, Scenedesmus } \\
\text { obliquus }\end{array}$ & $\begin{array}{l}\text { Algal cells, } \\
\text { AOM }\end{array}$ & $\begin{array}{l}\text { Forward osmosis FS } \\
\text { Thin film composite membrane } \\
\text { (TFC) }\end{array}$ & $\begin{array}{l}\uparrow \text { foulant-membrane interfacial energy } \rightarrow \downarrow \text { filterability } \\
\text { Upper cake layer: } \uparrow \text { solids and algal cells } \\
\text { A chemically desorbing layer: } \uparrow \text { organics } \\
\uparrow \text { cell size of } \mathrm{S} \text {. obliquus } \rightarrow \uparrow \text { adhesion of AOM on } \\
\text { membrane } \rightarrow \downarrow \text { filterability }\end{array}$ & Zhang Z. et al., 2020 \\
\hline Microcystis aeruginosa & $\begin{array}{l}\text { TEP (bond } \\
\text { and free) }\end{array}$ & $\begin{array}{l}\text { UF PVDF hollow fiber } \\
0.01-1 \mu \mathrm{m}\end{array}$ & $\begin{array}{l}\text { bTEP } \rightarrow \uparrow \text { reversible fouling } \\
\text { fTEP } \rightarrow \uparrow \text { irreversible fouling }\end{array}$ & Zhang Z. et al., 2020 \\
\hline
\end{tabular}

$\rightarrow$ leads to, $\downarrow$ less or reduced, $\uparrow$ more or increased, +added effect of a second factor, ++ is used to describe quantities particularly larger, $\uparrow \uparrow$ is used ti denote drastic increases in effects or concentrations.

2018). Therefore, traditional fouling control techniques differed essentially by the targeted final products, although significant similarities have emerged in recent years, as algal production has been coupled to wastewater treatment (Liao et al., 2018; Liu et al., 2018).

The first group of algal fouling control strategies attempted to modify the filterability properties of algal foulants present in the feed solution, using pretreatment methods and controls in operation. Feed pretreatment relies on the use of coagulants and adsorbents to promote the formation of cells and AOM aggregates that, in turn, are easily removed from the membrane surface and show better filterability properties upon attachment (Huang et al., 2019; Xing et al., 2019; Zhang Y. et al., 2020; $\mathrm{Xu}$ et al., 2021). Alternatively, oxidants are increasingly used in pretreatment to reduce and mineralize the concentration of the smaller organics fraction responsible for irreversible fouling (Liu et al., 2018; Lee et al., 2019, 2021; Wan et al., 2019; Ren et al., 2020). Despite their positive impacts on the fouling mitigation, primary challenges arose from concerns related to the effect of the chemical agents on the algal biomass, their release into the environment, and the high energy and capital expenses demanded by these techniques (Discart et al., 2015; Alshahri et al., 2021b).

Membrane operation is often controlled to target specific flux and cross-flow velocity (CFV), whereby the attractive forces between foulants and membrane are reduced by increasing the shear rates in the reactor (Liao et al., 2018; Zhang and Fu, 2018; Bamba et al., 2021). Moreover, operating parameters, such as the HRT and SRT, might be adjusted to control the rates of EOM/IOM generation and, thereby, the characteristics of the aggregates and prevailing fouling mechanism (Low et al., 2016; Novoa et al., 2020).

More recently, upon improved knowledge of membrane fouling, a second generation of control strategies has focused on the disruption of foulant-foulant and foulant-membrane interactions by mechanical means in dynamic filtration systems and by modifications of membrane materials and surface geometry (Ladner et al., 2010; Zhang and Fu, 2018; Zhang Y. et al., 2019). Membrane modifications have been recently applied by coating the surface with polymers and inorganic nanoparticles, aiming to control the overall electrostatic repulsion/attraction and hydrophobic/hydrophilic interactions in the membrane-foulant interface (Liu et al., 2019; Soleimani et al., 2021; Zhao et al., 2021a; Zheng et al., 2021). Hence, recent efforts in surface coating with hydrophilic monomers, surface grafting with hydrophilic polymer bushes, and nanomaterial incorporation have been developed to improve the filtration performance (Hu et al., 2015; Liao et al., 2018; Liu et al., 2019; Ma et al., 2020; Mat Nawi et al., 2020). In addition, the incorporation of $\mathrm{TiO}_{2}, \mathrm{Fe}_{2} \mathrm{O}_{3}$, zeolites, silica, and silver has been found to increase the hydrophilicity of the membrane, thereby enhancing the permeate flux (Hu et al., 2015). However, the significantly higher energy demand and the increase in the cost exerted by these modifications represent a bottleneck for these approaches, and, therefore, developing cost-efficient antifouling membrane materials and geometries with high hydrophilicity and mechanical resistance remains a subject of study (Ladner et al., 2010; Zhang and Fu, 2018; Zhang Y. et al., 2019; Zhao et al., 2021b). To this extent, it is necessary to integrate these aspects into the developments of fouling control technology, while comparative techno-economic and environmental assessments of fouling control strategies should be evaluated to decrease the cost and the environmental impact of the process.

\section{FUTURE PERSPECTIVES AND CONCLUSIONS}

This paper focuses on a comprehensive literature review on precursors and mechanisms of algal fouling. It was found out that the properties affecting the interactions in the membranefeed interface directly impact the fouling mechanism and its overall contribution to the membrane filtration performance. The characteristics of algal cells, AOM, and TEP, as well as their roles in membrane fouling, were reviewed. Algal cells are the main fouling contributor, leading to high reversible resistance that is easily removed by cleaning means; a cake layer, made of large and rigid cells with spherical shapes, is reported to present the best filterability properties, while these aspects are strongly determined by the algal species. On the other hand, $\mathrm{AOM}$ is the main contributor of irreversible fouling; it is mainly composed of hydrophobic proteins that form gel-like structures and hydrophilic carbohydrates that irreversibly attach to the membrane pores and surfaces. Controlling operating conditions to minimize the release of IOM and small-MW organics and promoting the aggregation of $\mathrm{AOM}$ and algal cells into larger 
particles are considered key factors to mitigate membrane fouling and to reach longer cycles of biomass harvesting. Moreover, understanding the underlying mechanisms responsible for the release of TEP into the solution remains a priority in fouling control.

Over recent years, different fouling control techniques have been developed in algal processes based on a growing understanding of the underlying interactions between the foulants and membrane surfaces. These strategies include changes in the operating conditions, pretreating the feed via coagulation, adsorption, or oxidation, cleaning the membranes by physical or mechanical means, and modifying the membrane surfaces by coatings or blends with polymers and nanoparticles. Despite the impact on membrane operation, very limited studies exist on real-time fouling characterization, and current assessments rely on indirect fouling indicators, such as TMP and concentration of foulants. Thereby, novel fouling characterization and assessment techniques to further understand the interaction between algal foulants and a membrane surface demand further study.

In spite of recent progress in control strategies, fouling remains the main challenge for membrane-based algal technologies. Understanding algal fouling still presents major

\section{REFERENCES}

Adhikari, B., and Pellegrino, J. (2015). Life-cycle assessment of five microalgae-tobiofuels processes of varying complexity. J. Renew. Sustain. Energy 7:043136. doi: 10.1063/1.4929462

Alshahri, A. H., Fortunato, L., Ghaffour, N., and Leiknes, T. (2021a). Controlling harmful algal blooms (HABs) by coagulation-flocculationsedimentation using liquid ferrate and clay. Chemosphere 274:129676. doi: 10.1016/j.chemosphere.2021.129676

Alshahri, A. H., Fortunato, L., Zaouri, N., Ghaffour, N., and Leiknes, T. (2021b). Role of dissolved air flotation (DAF) and liquid ferrate on mitigation of algal organic matter (AOM) during algal bloom events in RO desalination. Separat. Purif. Technol. 256:117795. doi: 10.1016/j.seppur.2020.117795

Ashadullah, A. K. M., Shafiquzzaman, M., Haider, H., Alresheedi, M., Azam, M. S., and Ghumman, A. R. (2021). Wastewater treatment by microalgal membrane bioreactor: evaluating the effect of organic loading rate and hydraulic residence time. J. Environ. Manage. 278:111548. doi: 10.1016/j.jenvman.2020.111548

Babel, S., and Takizawa, S. (2010). Microfiltration membrane fouling and cake behavior during algal filtration. Desalination 261, 46-51. doi: 10.1016/j.desal.2010.05.038

Baerdemaeker, T. D., Lemmens, B., Dotremont, C., Fret, J., Roef, L., Goiris, K., et al. (2013). Benchmark study on algae harvesting with backwashable submerged flat panel membranes. Bioresour. Technol. 129, 582-591. doi: 10.1016/j.biortech.2012.10.153

Bagheri, M., and Mirbagheri, S. A. (2018). Critical review of fouling mitigation strategies in membrane bioreactors treating water and wastewater. Bioresour. Technol. 258, 318-334. doi: 10.1016/j.biortech.2018.03.026

Bamba, B. S. B., Tranchant, C. C., Ouattara, A., and Lozano, P. (2021). Harvesting of microalgae biomass using ceramic microfiltration at high cross-flow velocity. Appl. Biochem. Biotechnol. 193, 1147-1169. doi: 10.1007/s12010-020-03455-y

Barbusiński, K., and Kościelniak, H. (1995). Influence of substrate loading intensity on floc size in activated sludge process. Water Res. 29, 1703-1710. doi: 10.1016/0043-1354(94)00326-3

Berman, T., and Holenberg, M. (2005). Don't fall foul of biofilm through high TEP levels. Filtrat. Separat. 42, 30-32. doi: 10.1016/S0015-1882(05)70517-6

Bilad, M. R., Arafat, H. A., and Vankelecom, I. F. J. (2014). Membrane technology in microalgae cultivation and harvesting: a review. Biotechnol. Adv. 32, 1283-1300. doi: 10.1016/j.biotechadv.2014.07.008 knowledge gaps; the dynamics across the cake layer impacting the cake porosity and overall filterability demand further research. Further understanding of these dynamics might drive the development of novel in-situ membrane fouling control systems, whereby localized shear rates or cleaning minimizes the cell breakage in solution while reducing the overall resistance of gel and a cake layer. Likewise, environmental considerations should be integrated in the future fouling control developments, aiming to optimize their economic performance of algal separation processes and minimize environmental impacts.

\section{AUTHOR CONTRIBUTIONS}

AN and LF: conceptualization and investigation. AN: writingoriginal draft preparation. LF, AN, and JV: writing-review and editing. All authors have read and agreed to the published version of the manuscript.

\section{FUNDING}

The research reported in this paper was supported by funding from King Abdullah University of Science and Technology (KAUST).

Bilad, M. R., Azizo, A. S., Wirzal, M. D. H., Jia Jia, L., Putra, Z. A., Nordin, N A. H. M., et al. (2018). Tackling membrane fouling in microalgae filtration using nylon 6,6 nanofiber membrane. J. Environ. Manage. 223, 23-28. doi: 10.1016/j.jenvman.2018.06.007

Bilad, M. R., Discart, V., Vandamme, D., Foubert, I., Muylaert, K., and Vankelecom, I. F. (2013). Harvesting microalgal biomass using a magnetically induced membrane vibration (MMV) system: filtration performance and energy consumption. Bioresour Technol. 138, 329-338. doi: 10.1016/j.biortech.2013.03.175

Bin, L., Qu, F., Liang, H., Gan, Z., Yu, H., Li, G., et al. (2017). Algae-laden water treatment using ultrafiltration: individual and combined fouling effects of cells, debris, extracellular and intracellular organic matter. J. Memb. Sci. 528, 178-186. doi: 10.1016/j.memsci.2017.01.032

Blumreisinger, M., Meindl, D., and Loos, E. (1983). Cell wall composition of chloreococcal algae. Phytochemistry 22, 1603-1604. doi: 10.1016/0031-9422(83)80096-X

BouNehme Sawaya, C., and Harb, M. (2021). Considering the prospect of utilizing anaerobic membrane biofouling layers advantageously for the removal of emerging contaminants. Front. Chem. Eng. 3:642280. doi: $10.3389 /$ fceng. 2021.642280

Bourcier, D., Féraud, J. P., Colson, D., Mandrick, K., Ode, D., Brackx, E., et al. (2016). Influence of particle size and shape properties on cake resistance and compressibility during pressure filtration. Chem. Eng. Sci. 144, 176-187. doi: 10.1016/j.ces.2016.01.023

Chen, X., Huang, C., and Liu, T. (2012). Harvesting of microalgae Scenedesmus sp. using polyvinylidene fluoride microfiltration membrane. Desalination Water Treat. 45, 177-181. doi: 10.1080/19443994.2012.692034

Deng, L., Guo, W., Ngo, H. H., Zhang, H., Wang, J., Li, J., et al. (2016). Biofouling and control approaches in membrane bioreactors. Bioresour. Technol. 221, 656-665. doi: 10.1016/j.biortech.2016.09.105

Discart, V., Bilad, M. R., Moorkens, R., Arafat, H., and Vankelecom, I. F. J. (2015). Decreasing membrane fouling during Chlorella vulgaris broth filtration via membrane development and coagulant assisted filtration. Algal Res. 9, 55-64. doi: $10.1016 /$ j.algal.2015.02.029

Elcik, H., and Cakmakci, M. (2017). Harvesting microalgal biomass using crossflow membrane filtration: critical flux, filtration performance, and fouling characterization. Environ. Technol. 38, 1585-1596. doi: $10.1080 / 09593330.2016 .1237560$ 
Eliseus, A., Bilad, M. R., Nordin, N., Putra, Z. A., and Wirzal, M. D. H. (2017). Tilted membrane panel: a new module concept to maximize the impact of air bubbles for membrane fouling control in microalgae harvesting. Bioresour. Technol. 241, 661-668. doi: 10.1016/j.biortech.2017.05.175

Fletcher, H., Verrecht, B., Nopens, I. (2011a). “Appendix B - MBR biotreatment base parameter values," in The MBR Book, 2nd Edn. (Oxford: ButterworthHeinemann), 457-461.

Fletcher, H., Verrecht, B., Nopens, I. (2011b). "Chapter 2 - fundamentals," in The MBR Book, 2nd Edn. (Oxford: Butterworth-Heinemann), 55-207.

Fortunato, L., Lamprea, A. F., and Leiknes, T. (2020). Evaluation of membrane fouling mitigation strategies in an algal membrane photobioreactor (AMPBR) treating secondary wastewater effluent. Sci. Total Environ. 708:134548. doi: 10.1016/j.scitotenv.2019.134548

Fortunato, L., Qamar, A., Wang, Y., Jeong, S., and Leiknes, T. (2017). In-situ assessment of biofilm formation in submerged membrane system using optical coherence tomography and computational fluid dynamics. J. Memb. Sci. 521, 84-94. doi: 10.1016/j.memsci.2016.09.004

Gonçalves, A. L., Pires, J. C. M., and Simões, M. (2017). A review on the use of microalgal consortia for wastewater treatment. Algal Res. 24, 403-415. doi: 10.1016/j.algal.2016.11.008

González-Camejo, J., Viruela, A., Ruano, M. V., Barat, R., Seco, A., and Ferrer, J. (2019). Effect of light intensity, light duration and photoperiods in the performance of an outdoor photobioreactor for urban wastewater treatment. Algal Res. 40:101511. doi: 10.1016/j.algal.2019.101511

Henderson, R. K., Baker, A., Parsons, S. A., and Jefferson, B. (2008). Characterisation of algogenic organic matter extracted from cyanobacteria, green algae and diatoms. Water Res. 42, 3435-3445. doi: 10.1016/j.watres.2007.10.032

$\mathrm{Hu}$, W., Yin, J., Deng, B., and $\mathrm{Hu}, \mathrm{Z}$. (2015). Application of nano $\mathrm{TiO}_{2}$ modified hollow fiber membranes in algal membrane bioreactors for high-density algae cultivation and wastewater polishing. Bioresour Technol. 193, 135-141. doi: 10.1016/j.biortech.2015.06.070

Hua, L., Cao, H., Ma, Q., Shi, X., Zhang, X., and Zhang, W. (2020). Microalgae filtration using an electrochemically reactive ceramic membrane: filtration performances, fouling kinetics, and foulant layer characteristics. Environ. Sci. Technol. 54, 2012-2021. doi: 10.1021/acs.est.9b07022

Huang, W., Chu, H., and Dong, B. (2012). Characteristics of algogenic organic matter generated under different nutrient conditions and subsequent impact on microfiltration membrane fouling. Desalination 293, 104-111. doi: 10.1016/j.desal.2012.03.001

Huang, W., Qin, X., Dong, B., Zhou, W., and Lv, W. (2019). Fate and UF fouling behavior of algal extracellular and intracellular organic matter under the influence of copper ions. Sci. Total Environ. 649, 1643-1652. doi: 10.1016/j.scitotenv.2018.08.077

Javadi, N., Zokaee Ashtiani, F., Fouladitajar, A., and Moosavi Zenooz, A. (2014). Experimental studies and statistical analysis of membrane fouling behavior and performance in microfiltration of microalgae by a gas sparging assisted process. Bioresour. Technol. 162, 350-357. doi: 10.1016/j.biortech.2014.03.160

Jiang, S., Xiao, S., Chu, H., Zhao, F., Yu, Z., Zhou, X., et al. (2020). Intelligent mitigation of fouling by means of membrane vibration for algae separation: dynamics model, comprehensive evaluation, and critical vibration frequency. Water Res. 182:115972. doi: 10.1016/j.watres.2020.115972

Kanchanatip, E., Su, B.-R., Tulaphol, S., Den, W., Grisdanurak, N., and Kuo, C.-C. (2016). Fouling characterization and control for harvesting microalgae Arthrospira (Spirulina) maxima using a submerged, disc-type ultrafiltration membrane. Bioresour. Technol. 209, 23-30. doi: 10.1016/j.biortech.2016.02.081

Keyvan Hosseini, P., Pajoum Shariati, F., Delavari Amrei, H., and Heydarinasab, A. (2020). The influence of various orifice diameters on cake resistance and pore blocking resistance of a hybrid membrane photobioreactor (HMPBR). Separat. Purif. Technol. 235:116187. doi: 10.1016/j.seppur.2019.116187

Kim, J. Q., Lee, J. H., Park, J., Park, H., Lim, S.-M., Lee, C.-G., et al. (2020). New surface modification method to develop a PET-based membrane with enhanced ion permeability and organic fouling resistance for efficient production of marine microalgae. ACS Appl. Mater. Interfaces 12, 25253-25265. doi: 10.1021/acsami.0c00546

Krzeminski, P., Leverette, L., Malamis, S., and Katsou, E. (2017). Membrane bioreactors - a review on recent developments in energy reduction, fouling control, novel configurations, LCA and market prospects. J. Memb. Sci. 527, 207-227. doi: 10.1016/j.memsci.2016.12.010

Kusumocahyo, S. P., Ambani, S. K., Kusumadewi, S., Sutanto, H., Widiputri, D. I., and Kartawiria, I. S. (2020). Utilization of used polyethylene terephthalate (PET) bottles for the development of ultrafiltration membrane. J. Environ. Chem. Eng. 8:104381. doi: 10.1016/j.jece.2020.104381

Ladner, D. A., Vardon, D. R., and Clark, M. M. (2010). Effects of shear on microfiltration and ultrafiltration fouling by marine bloom-forming algae. J. Memb. Sci. 356, 33-43. doi: 10.1016/j.memsci.2010.03.024

Le-Clech, P., Jefferson, B., and Judd, S. J. (2005). A comparison of submerged and sidestream tubular membrane bioreactor configurations. Desalination 173, 113-122. doi: 10.1016/j.desal.2004.08.029

Lee, H., Lim, J., Zhan, M., and Hong, S. (2019). UV-LED/PMS preoxidation to control fouling caused by harmful marine algae in the UF pretreatment of seawater desalination. Desalination 467, 219-228. doi: 10.1016/j.desal.2019.06.009

Lee, J.-C., Park, R., Yoo, K. S., and Kim, H.-W. (2021). Coupling cold plasma and membrane photobioreactor for enhanced fouling control during livestock excreta treatment. Chemosphere 265:129031. doi: 10.1016/j.chemosphere.2020.129031

Liao, B. Q., Allen, D. G., Leppard, G. G., Droppo, I. G., and Liss, S. N. (2002). Interparticle interactions affecting the stability of sludge flocs. J. Colloid Interface Sci. 249, 372-380. doi: 10.1006/jcis.2002.8305

Liao, Y., Bokhary, A., Maleki, E., and Liao, B. (2018). A review of membrane fouling and its control in algal-related membrane processes. Bioresour. Technol. 264, 343-358. doi: 10.1016/j.biortech.2018.06.102

Liu, B., Qu, F., Liang, H., Van der Bruggen, B., Cheng, X., Yu, H., et al. (2017). Microcystis aeruginosa-laden surface water treatment using ultrafiltration: membrane fouling, cell integrity and extracellular organic matter rejection. Water Res. 112, 83-92. doi: 10.1016/j.watres.2017.01.033

Liu, B., Qu, F., Yu, H., Tian, J., Chen, W., Liang, H., et al. (2018). Membrane fouling and rejection of organics during algae-laden water treatment using ultrafiltration: a comparison between in situ pretreatment with $\mathrm{Fe}(\mathrm{II}) /$ persulfate and ozone. Environ. Sci. Technol. 52, 765-774. doi: 10.1021/acs.est.7b03819

Liu, Q., Demirel, E., Chen, Y., Gong, T., Zhang, X., and Chen, Y. (2019). Improving antifouling performance for the harvesting of Scenedesmus acuminatus using $\mathrm{Fe}_{2} \mathrm{O}_{3}$ nanoparticles incorporated PVC nanocomposite membranes. J. Appl. Polymer Sci. 136:47685. doi: 10.1002/app.47685

Logan, B. E., Passow, U., Alldredge, A. L., Grossartt, H.-P., and Simont, M. (1995). Rapid formation and sedimentation of large aggregates is predictable from coagulation rates (half-lives) of transparent exopolymer particles (TEP). Deep Sea Res. Part II Topical Stud. Oceanogr. 42, 203-214. doi: 10.1016/0967-0645(95)00012-F

Low, S. L., Ong, S. L., and Ng, H. Y. (2016). Characterization of membrane fouling in submerged ceramic membrane photobioreactors fed with effluent from membrane bioreactors. Chem. Eng. J. 290, 91-102. doi: 10.1016/j.cej.2016.01.005

Luo, Y., Henderson, R. K., and Le-Clech, P. (2019). Characterisation of organic matter in membrane photobioreactors (MPBRs) and its impact on membrane performance. Algal Res. 44:101682. doi: 10.1016/j.algal.2019.101682

Luo, Y., Le-Clech, P., and Henderson, R. K. (2017). Simultaneous microalgae cultivation and wastewater treatment in submerged membrane photobioreactors: a review. Algal Res. 24, 425-437. doi: 10.1016/j.algal.2016.10.026

Ma, C., Yi, C., Li, F., Shen, C., Wang, Z., Sand, W., and Liu, Y. (2020). Mitigation of membrane fouling using an electroactive polyether sulfone membrane. Membranes 10:21. doi: 10.3390/membranes 10020021

Marbelia, L., Bilad, M. R., Maes, S. E., Arafat, H., and Vankelecom, I. (2018). Poly(vinylidene fluoride)-based membranes for microalgae filtration. Chem. Eng. Technol. 41, 1305-1312. doi: 10.1002/ceat.201700622

Marbelia, L., Bilad, M. R., Passaris, I., Discart, V., Vandamme, D., Beuckels, A., et al. (2014). Membrane photobioreactors for integrated microalgae cultivation and nutrient remediation of membrane bioreactors effluent. Bioresour. Technol. 163, 228-235. doi: 10.1016/j.biortech.2014.04.012

Marbelia, L., Mulier, M., Vandamme, D., Muylaert, K., Szymczyk, A., and Vankelecom, I. F. J. (2016). Polyacrylonitrile membranes for microalgae filtration: influence of porosity, surface charge and microalgae species 
on membrane fouling. Algal Res. 19, 128-137. doi: 10.1016/j.algal.2016. 08.004

Mat Nawi, N. I., Abd Halim, N. S., Lee, L. C., Wirzal, M. D. H., Bilad, M. R., Nordin, N. A. H., et al. (2020). Improved nylon 6,6 nanofiber membrane in a tilted panel filtration system for fouling control in microalgae harvesting. Polymers 12:252. doi: $10.3390 /$ polym 12020252

Medina, M., and Neis, U. (2007). Symbiotic algal bacterial wastewater treatment: effect of food to microorganism ratio and hydraulic retention time on the process performance. Water Sci. Technol. 55:165. doi: 10.2166/wst.2007.351

Metcalf, L., and Eddy, I. (2003). Wastewater Engineering: Treatment and Reuse, 4th Edn. revised by George Tchobanoglous, Burton, F. L., and Stensel, H. D. Boston, MA: McGraw-Hill.

Morineau-Thomas, O., Jaouen, P., and Legentilhomme, P. (2002). The role of exopolysaccharides in fouling phenomenon during ultrafiltration of microalgae (Chlorella sp. and Porphyridium purpureum): advantage of a swirling decaying flow. Bioprocess Biosyst. Eng. 25, 35-42. doi: 10.1007/s00449-001-0278-1

Mu, D., Min, M., Krohn, B., Mullins, K. A., Ruan, R., and Hill, J. (2014). Life cycle environmental impacts of wastewater-based algal biofuels. Environ. Sci. Technol. 48, 11696-11704. doi: 10.1021/es5027689

Novoa, A. F., Fortunato, L., Rehman, Z. U., and Leiknes, T. (2020). Evaluating the effect of hydraulic retention time on fouling development and biomass characteristics in an algal membrane photobioreactor treating a secondary wastewater effluent. Bioresour. Technol. 309:123348. doi: $10.1016 /$ j.biortech.2020.123348

Ozkan, A., and Berberoglu, H. (2013). Adhesion of algal cells to surfaces. Biofouling 29, 469-482. doi: 10.1080/08927014.2013.782397

Passow, U., Shipe, R. F., Murray, A., Pak, D. K., Brzezinski, M. A., and Alldredge, A. L. (2001). The origin of transparent exopolymer particles (TEP) and their role in the sedimentation of particulate matter. Continental Shelf Res. 21, 327-346. doi: 10.1016/S0278-4343(00)00101-1

Qu, F., Liang, H., He, J., Ma, J., Wang, Z., Yu, H., et al. (2012). Characterization of dissolved extracellular organic matter (dEOM) and bound extracellular organic matter (bEOM) of Microcystis aeruginosa and their impacts on UF membrane fouling. Water Res. 46, 2881-2890. doi: 10.1016/j.watres.2012.02.045

Ren, Z., Cheng, X., Li, P., Luo, C., Tan, F., Zhou, W., et al. (2020). Ferrousactivated sodium percarbonate pre-oxidation for membrane fouling control during ultrafiltration of algae-laden water. Sci. Total Environ. 739:140030. doi: 10.1016/j.scitotenv.2020.140030

Rickman, M., Pellegrino, J., and Davis, R. (2012). Fouling phenomena during membrane filtration of microalgae. J. Memb. Sci. 423-424, 33-42. doi: 10.1016/j.memsci.2012.07.013

Roostaei, J., and Zhang, Y. (2017). Spatially explicit life cycle assessment: opportunities and challenges of wastewater-based algal biofuels in the United States. Algal Res. 24, 395-402. doi: 10.1016/j.algal.2016.08.008

Senatore, V., Buonerba, A., Zarra, T., Oliva, G., Belgiorno, V., BoguniewiczZablocka, J., et al. (2021). Innovative membrane photobioreactor for sustainable $\mathrm{CO}_{2}$ capture and utilization. Chemosphere 273:129682. doi: 10.1016/j.chemosphere.2021.129682

Shekhar, M., Shriwastav, A., Bose, P., and Hameed, S. (2017). Microfiltration of algae: impact of algal species, backwashing mode and duration of filtration cycle. Algal Res. 23, 104-112. doi: 10.1016/j.algal.2017.01.013

Shi, R., Handler, R. M., and Shonnard, D. R. (2019). Life cycle assessment of novel technologies for algae harvesting and oil extraction in the renewable diesel pathway. Algal Res. 37, 248-259. doi: 10.1016/j.algal.2018.12.005

Soleimani, S., Jannesari, A., Yousefzadi, M., Ghaderi, A., and Shahdadi, A. (2021). Eco-friendly foul release coatings based on a novel reduced graphene oxide/Ag nanocomposite prepared by a green synthesis approach. Progress Org. Coatings 151:106107. doi: 10.1016/j.porgcoat.2020.106107

Sun, L., Tian, Y., Li, H., and Wang, Q. (2021). Fouling potentials and properties of foulants in an innovative algal-sludge membrane bioreactor. Environ. Int. 151:106439. doi: 10.1016/j.envint.2021.106439

Ting, H. H., Haifeng L, Shanshan, M., Zhang, Y., Zhidan, L., and Na, D. (2017). Progress in microalgae cultivation photobioreactors and applications in wastewater treatment: a review. Int. J. Agric. Biol. Eng. 10, 1-29. doi: 10.3965/j.ijabe.20171001.2705

Tua, C., Ficara, E., Mezzanotte, V., and Rigamonti, L. (2021). Integration of a side-stream microalgae process into a municipal wastewater treatment plant: a life cycle analysis. J. Environ. Manage. 279:111605 doi: 10.1016/j.jenvman.2020.111605

Wan, Y., Xie, P., Wang, Z., Ding, J., Wang, J., Wang, S., et al. (2019). Comparative study on the pretreatment of algae-laden water by UV/persulfate, UV/chlorine, and $\mathrm{UV} / \mathrm{H}_{2} \mathrm{O}_{2}$ : variation of characteristics and alleviation of ultrafiltration membrane fouling. Water Res. 158, 213-226. doi: 10.1016/j.watres.2019. 04.034

Wang, Z., Ma, J., Tang, C. Y., Kimura, K., Wang, Q., and Han, X. (2014). Membrane cleaning in membrane bioreactors: a review. J. Memb. Sci. 468, 276-307. doi: 10.1016/j.memsci.2014.05.060

Wicaksana, F., Fane, A. G., Pongpairoj, P., and Field, R. (2012). Microfiltration of algae (Chlorella sorokiniana): critical flux, fouling and transmission. J. Memb. Sci. 387-388, 83-92. doi: 10.1016/j.memsci.2011.10.013

Wu, B., Kitade, T., Chong, T. H., Lee, J. Y., Uemura, T., and Fane, A. G. (2013). Flux-dependent fouling phenomena in membrane bioreactors under different food to microorganisms (F/M) ratios. Separat. Sci. Technol. 48, 840-848. doi: 10.1080/01496395.2012.724501

Wu, L., and Sancaktar, E. (2020). Effect of PET support membrane thickness on water permeation behavior of thermally responsive PNIPAM-g-PET membranes. J. Memb. Sci. 610:118304. doi: 10.1016/j.memsci.2020.118304

Wu, X., Zhou, C., Li, K., Zhang, W., and Tao, Y. (2018). Probing the fouling process and mechanisms of submerged ceramic membrane ultrafiltration during algal harvesting under sub- and super-critical fluxes. Separat. Purif. Technol. 195, 199-207. doi: 10.1016/j.seppur.2017.12.001

Xing, J., Liang, H., Xu, S., Chuah, C. J., Luo, X., Wang, T., et al. (2019). Organic matter removal and membrane fouling mitigation during algae-rich surface water treatment by powdered activated carbon adsorption pretreatment: enhanced by UV and UV/chlorine oxidation. Water Res. 159, 283-293. doi: 10.1016/j.watres.2019.05.017

Xu, J., Zhao, Y., Gao, B., Han, S., Zhao, Q., and Liu, X. (2018). The influence of algal organic matter produced by Microcystis aeruginosa on coagulationultrafiltration treatment of natural organic matter. Chemosphere 196, 418-428. doi: 10.1016/j.chemosphere.2017.12.198

$\mathrm{Xu}$, M., Li, P., Tang, T., and Hu, Z. (2015). Roles of SRT and HRT of an algal membrane bioreactor system with a tanks-in-series configuration for secondary wastewater effluent polishing. Ecol. Eng. 85, 257-264. doi: 10.1016/j.ecoleng.2015.09.064

Xu, M., Wang, X., Zhou, B., and Zhou, L. (2021). Pre-coagulation with cationic flocculant-composited titanium xerogel coagulant for alleviating subsequent ultrafiltration membrane fouling by algae-related pollutants. J. Hazard. Mater. 407:124838. doi: 10.1016/j.jhazmat.2020.124838

Yogarathinam, L. T., Gangasalam, A., Ismail, A. F., and Parthasarathy, P. (2018). Harvesting of microalgae Coelastrella sp. FI69 using pore former induced $\mathrm{TiO}_{2}$ incorporated PES mixed matrix membranes. J. Chem. Technol. Biotechnol. 93, 645-655. doi: 10.1002/jctb.5495

Zevin, A. S., Nam, T., Rittmann, B., and Krajmalnik-Brown, R. (2015). Effects of phosphate limitation on soluble microbial products and microbial community structure in semi-continuous synechocystis-based photobioreactors. Biotechnol. Bioeng. 112, 1761-1769. doi: 10.1002/bit.25602

Zhang, M., Leung, K.-T., Lin, H., and Liao, B. (2020). The biological performance of a novel microalgal-bacterial membrane photobioreactor: effects of HRT and N/P ratio. Chemosphere 261:128199. doi: 10.1016/j.chemosphere.2020.128199

Zhang, M., Yao, L., Maleki, E., Liao, B.-Q., and Lin, H. (2019). Membrane technologies for microalgal cultivation and dewatering: recent progress and challenges. Algal Res. 44:101686. doi: 10.1016/j.algal.2019.101686

Zhang, W., Zhang, W., Zhang, X., Amendola, P., Hu, Q., and Chen, Y. (2013). Characterization of dissolved organic matters responsible for ultrafiltration membrane fouling in algal harvesting. Algal Res. 2, 223-229. doi: 10.1016/j.algal.2013.05.002

Zhang, X., Devanadera, M. C. E., Roddick, F. A., Fan, L., and Dalida, M. L. P. (2016). Impact of algal organic matter released from Microcystis aeruginosa and Chlorella sp. on the fouling of a ceramic microfiltration membrane. Water Res. 103, 391-400. doi: 10.1016/j.watres.2016.07.061

Zhang, X., Fan, L., and Roddick, F. A. (2013). Influence of the characteristics of soluble algal organic matter released from Microcystis aeruginosa on the fouling of a ceramic microfiltration membrane. J. Memb. Sci. 425-426, 23-29. doi: 10.1016/j.memsci.2012.09.033 
Zhang, Y., Fu, B., Wang, X., Ma, C., Lin, L., Fu, Q., et al. (2020). Algal fouling control in low-pressure membrane systems by pre-adsorption: influencing factors and mechanisms. Algal Res. 52:102110. doi: 10.1016/j.algal.2020.102110

Zhang, Y., and Fu, Q. (2018). Algal fouling of microfiltration and ultrafiltration membranes and control strategies: a review. Separat. Purif. Technol. 203, 193-208. doi: 10.1016/j.seppur.2018.04.040

Zhang, Y., Wang, X., Jia, H., Fu, B., Xu, R., and Fu, Q. (2019). Algal fouling and extracellular organic matter removal in powdered activated carbon-submerged hollow fiber ultrafiltration membrane systems. Sci. Total Environ. 671, 351-361. doi: 10.1016/j.scitotenv.2019.03.371

Zhang, Y., Zhao, Y., Chu, H., Zhou, X., and Dong, B. (2014). Dewatering of Chlorella pyrenoidosa using diatomite dynamic membrane: filtration performance, membrane fouling and cake behavior. Colloids Surfaces B Biointerfaces 113, 458-466. doi: 10.1016/j.colsurfb.2013.09.046

Zhang, Z., Chen, M., Li, J., Zhao, B., and Wang, L. (2020). Significance of transparent exopolymer particles derived from aquatic algae in membrane fouling. Arab. J. Chem. 13, 4577-4585. doi: 10.1016/j.arabjc.2019.10.004

Zhao, F., Chu, H., Yu, Z., Jiang, S., Zhao, X., Zhou, X., et al. (2017). The filtration and fouling performance of membranes with different pore sizes in algae harvesting. Sci. Total Environ. 587-588, 87-93. doi: 10.1016/j.scitotenv.2017.02.035

Zhao, F., Su, Y., Tan, X., Chu, H., Zhang, Y., Yang, L., et al. (2015). Effect of temperature on extracellular organic matter (EOM) of Chlorella pyrenoidosa and effect of EOM on irreversible membrane fouling. Colloids Surfaces B Biointerfaces 136, 431-439. doi: 10.1016/j.colsurfb.2015.09.031

Zhao, F., Zhang, Y., Chu, H., Jiang, S., Yu, Z., Wang, M., et al. (2018). A uniform shearing vibration membrane system reducing membrane fouling in algae harvesting. J. Clean. Prod. 196, 1026-1033. doi: 10.1016/j.jclepro.2018.06.089

Zhao, Z., Liu, B., Ilyas, A., Vanierschot, M., Muylaert, K., and Vankelecom, I. F. J. (2021a). Harvesting microalgae using vibrating, negatively charged, patterned polysulfone membranes. J. Memb. Sci. 618:118617. doi: 10.1016/j.memsci.2020.118617
Zhao, Z., Muylaert, K., Szymczyk, A., and Vankelecom, I. F. J. (2021b). Harvesting microalgal biomass using negatively charged polysulfone patterned membranes: influence of pattern shapes and mechanism of fouling mitigation. Water Res. 188:116530. doi: 10.1016/j.watres.2020.116530

Zheng, M., Yang, Y., Qiao, S., Zhou, J., and Quan, X. (2021). A porous carbon-based electro-Fenton hollow fiber membrane with good antifouling property for microalgae harvesting. J. Memb. Sci. 626:119189. doi: 10.1016/j.memsci.2021.119189

Zhou, H., Ji, C.-C., Li, J.-Q., Hu, Y.-X., Xu, X.-H., An, Y., et al. (2020). Understanding the interaction mechanism of algal cells and soluble algal products foulants in forward osmosis dewatering. J. Membr. Sci. 620:118835. doi: 10.1016/j.memsci.2020.118835

Zhou, S., Shao, Y., Gao, N., Li, L., Deng, J., Tan, C., et al. (2014). Influence of hydrophobic/hydrophilic fractions of extracellular organic matters of Microcystis aeruginosa on ultrafiltration membrane fouling. Sci. Total Environ. 470-471, 201-207. doi: 10.1016/j.scitotenv.2013.09.052

Zhuang, L.-L., Wu, Y.-H., Espinosa, V. M. D., Zhang, T.-Y., Dao, G.-H., and Hu, H.-Y. (2016). Soluble Algal Products (SAPs) in large scale cultivation of microalgae for biomass/bioenergy production: a review. Renew. Sustain. Energy Rev. 59, 141-148. doi: 10.1016/j.rser.2015.12.352

Conflict of Interest: The authors declare that the research was conducted in the absence of any commercial or financial relationships that could be construed as a potential conflict of interest.

Copyright (c) 2021 Novoa, Vrouwenvelder and Fortunato. This is an open-access article distributed under the terms of the Creative Commons Attribution License (CC $B Y)$. The use, distribution or reproduction in other forums is permitted, provided the original author(s) and the copyright owner(s) are credited and that the original publication in this journal is cited, in accordance with accepted academic practice. No use, distribution or reproduction is permitted which does not comply with these terms. 